\title{
Inorganic Chemistry of Defensive Peroxidases in the Human Oral Cavity
}

\author{
M. T. Ashby \\ Department of Chemistry and Biochemistry, University of Oklahoma, \\ Norman, OK 73019, USA; MAshby@ou.edu \\ J Dent Res 87(10):900-914, 2008
}

\begin{abstract}
The innate host response system is comprised of various mechanisms for orchestrating host response to microbial infection of the oral cavity. The heterogeneity of the oral cavity and the associated microenvironments that are produced give rise to different chemistries that affect the innate defense system. One focus of this review is on how these spatial differences influence the two major defensive peroxidases of the oral cavity, salivary peroxidase (SPO) and myeloperoxidase (MPO). With hydrogen peroxide $\left(\mathrm{H}_{2} \mathrm{O}_{2}\right)$ as an oxidant, the defensive peroxidases use inorganic ions to produce antimicrobials that are generally more effective than $\mathrm{H}_{2} \mathrm{O}_{2}$ itself. The concentrations of the inorganic substrates are different in saliva $v s$. gingival crevicular fluid (GCF). Thus, in the supragingival regime, SPO and MPO work in unison for the exclusive production of hypothiocyanite $\left(\mathrm{OSCN}^{-}\right.$, a reactive inorganic species), which constantly bathes nascent plaques. In contrast, MPO is introduced to the GCF during inflammatory response, and in that environment it is capable of producing hypochlorite $\left(\mathrm{OCl}^{-}\right)$, a chemically more powerful oxidant that is implicated in host tissue damage. A second focus of this review is on inter-person variation that may contribute to different peroxidase function. Many of these differences are attributed to dietary or smoking practices that alter the concentrations of relevant inorganic species in the oral cavity (e.g.: fluoride, $\mathrm{F}^{-}$; cyanide, $\mathrm{CN}^{-}$; cyanate, $\mathrm{OCN}^{-}$; thiocyanate, $\mathrm{SCN}^{-}$; and nitrate, $\mathrm{NO}_{3}^{-}$). Because of the complexity of the host and microflora biology and the associated chemistry, it is difficult to establish the significance of the human peroxidase systems during the pathogenesis of oral diseases. The problem is particularly complex with respect to the gingival sulcus and periodontal pockets (where the very different defensive stratagems of GCF and saliva co-mingle). Despite this complexity, intriguing in vitro and in vivo studies are reviewed here that reveal the interplay between peroxidase function and associated inorganic chemistry.
\end{abstract}

KEY WORDS: salivary peroxidase, myeloperoxidase, hypochlorite, hypothiocyanite.

Received April 1, 2008; Last revision May 26, 2008; Accepted June 25,2008

\section{INTRODUCTION}

$\mathbf{T}$ he oral cavity contains a plethora of specific and non-specific defense factors. The non-specific factors include some mucins, proline-rich proteins, salivary glycoproteins, lactoferrin, lysozyme, histatins, cystatins, and peroxidases. This review focuses on the role of peroxidases in the context of oral health and disease, with an emphasis on the relevant inorganic chemistry. Particular attention is paid to the antimicrobial properties of the inorganic chemicals of the oral cavity that are associated with the peroxidases, and to the inter-person differences in the inorganic chemistry of the oral cavity that may influence peroxidase function. For further information on the structures and origins of human oral peroxidases, the reader is referred to the recent review by Tenovuo and co-workers (Ihalin et al., 2006). There are two principal defensive peroxidase systems in the oral cavity, salivary peroxidase (SPO) and myeloperoxidase (MPO). SPO is structurally and catalytically similar to lactoperoxidase (LPO) (Ihalin et al., 2006). In vivo, the SPO and LPO systems essentially use only the pseudohalide $\mathrm{SCN}^{-}$as a substrate to produce $\mathrm{OSCN}^{-}$(Pruitt et al., 1988). Such defensive peroxidases are commonly found in regions of the human body that are controlled by the mucosa: e.g., breast milk (Shin et al., 2000), lachrymal fluid ( Van Haeringen et al., 1979; Tenovuo et al., 1985), and the mucosal lining of the lungs (Gerson et al., 2000). LPO and SPO are coded for the same gene (Ueda et al., 1997). In contrast to peroxidases that essentially employ only $\mathrm{SCN}^{-}$as a substrate (e.g., LPO and SPO), the MPO system is also capable of oxidizing $\mathrm{Cl}^{-}$to produce hypochlorite $\left(\mathrm{OCl}^{-}\right.$) (Arnhold et al., 2006). Hypobromite $\left(\mathrm{OBr}^{-}\right)$can also be generated by the MPO system (Thomas et al., 1995), but only in minor amounts in the oral cavity. All of the human defensive peroxidases can also utilize iodide $\left(\mathrm{I}^{-}\right)$as a substrate. However, because of sequestration in the thyroid, the environmentally rare halide $\mathrm{I}^{-}$is not abundant in most physiologic fluids, including the fluids of the oral cavity (Anttonen and Tenovuo, 1981). Accordingly, the limited bioavailability of $\mathrm{I}^{-}$ precludes its significant involvement in host defense.

SPO is a normal, non-inducible component of the saliva of the parotid and submandibular glands (Riva et al., 1978), whereas MPO is an offensive mechanism of neutrophilic polymorphonuclear leukocytes (PMNs). Leukocytes are not normal components of the saliva of healthy individuals, but rather are introduced to the oral cavity by gingival crevicular fluid (GCF) during inflammatory responses (Kowolik and Grant, 1983). The leukocytes in the GCF are comprised of ca. 90\% PMNs (Ebersole, 2003), and MPO accounts for about $5 \%$ of the total PMN protein (Pullar et al., 2000). PMNs degenerate in saliva due to osmotic lysis, thereby releasing the content of the azurophilic granules (including MPO). It has been estimated that $c a$. $75 \%$ of the peroxidase activity in mixed saliva is due to MPO, with the remaining activity attributed to SPO (Thomas et al., 1994a). Most of the SPO activity is associated with the soluble portion of the saliva, whereas most of the MPO activity is associated with the sediment (Thomas et al., 1994a). Note that, in contrast to other regions of the mucosa-for example, the lungs-eosinophils are not usually recruited into 


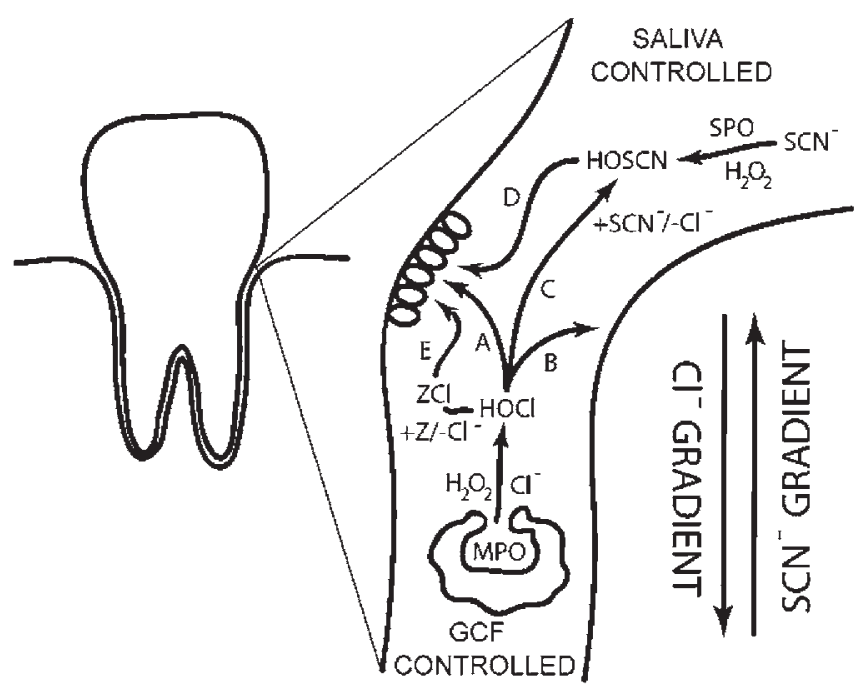

Figure 1. Spatial relationship between the inorganic host defense factors of the oral cavity and the ion gradients that influence their relative abundance. Refer to the text for an explanation of pathways A-E and the meaning of the variable $Z$.

the oral cavity, although they can be introduced to saliva via the sputum of individuals who have asthma eosinophilia (Spahn, 2007) and from eosinophilic ulcers (rare lesions of the oral mucosa) (Mezei et al., 1995; Hirshberg et al., 2006). Consequently, there is no evidence that eosinophil peroxidase (another common defensive peroxidase that has properties somewhat different from those of LPO, SPO, and MPO) plays a significant role in oral fluids. Accordingly, this review focuses on SPO and MPO.

\section{PEROXIDASES: ORAL HEALTH AND DISEASE}

The two disease states of the oral cavity that we consider here are caries and periodontal diseases. The etiology of caries is clear: Acidogenic bacteria cause damage to tooth enamel in the presence of fermentable carbohydrates (e.g., sucrose, fructose, and glucose) (Featherstone, 2000). When the $\mathrm{pH}$ at the surface of the tooth falls below 5.5, demineralization proceeds faster than remineralization, and decay ensues. The role of inorganic chemistry in this process is multifaceted: e.g., the (de)mineralization process largely involves the inorganic mineral hydroxyapatite [ca. $96 \%$ for enamel and $70 \%$ for dentin (with some amorphous calcium phosphate)], and the aforementioned peroxidase-derived reactive inorganic species are involved in controlling the microbial growth $\left(\mathrm{OSCN}^{-}\right.$in particular, although other inorganic chemical species have been proposed to be significant, vide infra).

Like caries, periodontal diseases are also caused by microbial infection (Smalley, 1994; Genco, 1996; Mombelli, 2003). Although the primary cause of periodontal diseases is the accumulation of dental plaque at the gingival margin and the consequential host response (Azuma, 2006), numerous factors affect the severity of the diseases, include smoking (Bergström, 2004), poorly controlled diabetes (Mealey and Oates, 2006), and genetic susceptibility (Baker and Roopenian, 2002; Shapira et al., 2005). Both soft tissues (gingival and periodontal ligaments) and hard tissues (alveolar bone and cementum, which are both largely hydroxyapatite) are
Table 1. Two-electron Redox Couples for $X^{-}\left(E^{\circ}, p H=7\right.$ vs. SHE), Apparent Rate Constants ( $k$ ) of MPO Compound I $\left(x 10^{-4} \mathrm{M}^{-1} \mathrm{~s}^{-1}\right)$ with $X$; a Reference Range Values (RRV) of $X^{-}$in Physiologic Fluids ( $\mu M$ or $\mathrm{mM}$ ), and Specificities $(S)^{b}$ for Oxidation of $X-$ by MPO (consensus substrates in bold)

\begin{tabular}{ccccccc}
$X^{-}$ & $E^{\circ}$ & $k$ & RRV in GCF & GCF S & RRV in Saliva & Saliva S \\
\hline Cl $^{-}$ & 1.08 & 2.5 & $90 \mathrm{mM}$ & 6 & $25 \mathrm{mM}$ & 1 \\
SCN $^{-}$ & 0.77 & 960 & $40 \mu \mathrm{M}$ & 1 & $1 \mathrm{mM}$ & 15
\end{tabular}

a Furtmueller et al. (1998).
b $S=\mathrm{k}^{\mathrm{x}^{-}}{ }_{\text {maj }}\left[\mathrm{X}_{\text {maj }}^{-}\right] / \mathrm{k}^{\mathrm{x}_{\text {min }}^{-}}\left[\mathrm{X}_{\min }^{-}\right]$

affected, but the cause of this tissue damage is a complex and as-yet-unresolved matter. It appears likely that inflammatory agents (including $\mathrm{OCl}^{-}$) produced by the host (Pullar et al., 2000; Klebanoff, 2005) and virulence factors produced by the infectious agents (Graves et al., 2000) are both responsible for the tissue damage. The supragingival environment in which caries develops and the subgingival environment of periodontal diseases exhibit different chemistries that have a marked influence on the functions and activities of the human defensive peroxidases, which will be discussed next (Fig. 1, Table 1).

\section{SPATIAL NATURE OF PEROXIDASE SYSTEMS AND THEIR CONSENSUS SUBSTRATES}

The oxidation reactions that are catalyzed by the peroxidase systems of the oral cavity are governed by the amount of available hydrogen peroxide $\left(\mathrm{H}_{2} \mathrm{O}_{2}\right)$, the limiting chemical reagent. A dual-oxidase system from the salivary glands is an endogenous source of $\mathrm{H}_{2} \mathrm{O}_{2}$ (Geiszt et al., 2003; Donko et al., 2005; Ris-Stalpers, 2006). Oral bacteria also produce $\mathrm{H}_{2} \mathrm{O}_{2}$ during anaerobic glycolysis (Carlsson et al., 1983). A third source of $\mathrm{H}_{2} \mathrm{O}_{2}$ is derived from activated neutrophils during oxidative bursts (Dahlgren and Karlsson, 1999; Quinn, 2005). The amounts of $\mathrm{OCl}^{-}$and $\mathrm{OSCN}^{-}$that are produced by the MPO system are related to the relative concentrations of $\mathrm{Cl}^{-}$and $\mathrm{SCN}^{-}$( van Dalen et al., 1997; Arnhold et al., 2006). At equal concentrations of (pseudo)halide, MPO catalyzes the oxidation of $\mathrm{SCN}^{-}$about 1000 times faster than $\mathrm{Cl}^{-}$, but $\mathrm{Cl}^{-}$is about 1000 times more abundant in most physiologic fluids [e.g., plasma and GCF (Anttonen and Tenovuo, 1981)]. Consequently, comparable amounts of $\mathrm{OSCN}^{-}$and $\mathrm{OCl}^{-}$are produced by the MPO system in such fluids. However, $\mathrm{SCN}^{-}$ is essentially the only substrate of MPO in saliva, where the concentration of $\mathrm{SCN}^{-}$is higher than in most other extracelluar fluids (Tenovuo and Makinen, 1976), as a consequence of its active transport (Fragoso et al., 2004). While analysis of the data in Table 1 suggests that $\mathrm{OCl}^{-}$should also be generated in saliva, albeit in a minor amount with respect to $\mathrm{OSCN}^{-}$, it can be estimated that the half-life of the $\mathrm{OCl}^{-}$in saliva is less than $15 \mu \mathrm{sec}$, as a consequence of its very fast non-enzymic reaction with $\mathrm{SCN}^{-}$(Ashby et al., 2004). The reaction of $\mathrm{OCl}^{-}$ and $\mathrm{SCN}^{-}$yields $\mathrm{OSCN}^{-}$(Nagy et al., 2006a). Thus, in effect, the only hypohalite of the SPO and MPO systems in saliva is 
expected to be $\mathrm{OSCN}^{-}$, but a continuum of products is expected at the gingival margin, where a gradient of concentration of $\mathrm{Cl}^{-}$and $\mathrm{SCN}^{-}$exists. The spatial relationship between these gradients and the areas of the oral cavity that are respectively controlled by the $\mathrm{OCl}^{-}$and $\mathrm{OSCN}^{-}$defense factors is illustrated in Fig. 1:

- Extraphagosomal $\mathrm{OCl}^{-}$is cytotoxic to oral bacteria (Path A) (Briseno et al., 1992; Webb et al., 1995; Yesilsoy et al., 1995; Barnard et al., 1996; Winniczuk and Parish, 1997; Calas et al., 1998; D’Arcangelo et al., 1998; D’Arcangelo and Varvara, 1998; Huque et al., 1998; Ferreira et al., 1999; Wunder and Bowen, 1999; Spratt et al., 2001; Mikami et al., 2003; Sassone et al., 2003a,b; Moller et al., 2004; Nagayoshi et al., 2004; Radcliffe et al., 2004; Vianna et al., 2004; Carson et al., 2005; Fang et al., 2006; Sena et al., 2006; Ozok et al., 2007) and gingival tissue (Path B) (Schraufstatter et al., 1990; Vissers et al., 1999; Hidalgo and Dominguez, 2000; Pullar et al., 2000; Vile et al., 2000; Hidalgo et al., 2002). Importantly, nearly all of the investigations of the efficacy of $\mathrm{OCl}^{-}$on oral bacteria have been carried out for single species in planktonic cultures. However, a recent study has focused on the effects of $\mathrm{OCl}^{-}$ on single- and dual-species biofilms of Fusobacterium nucleatum and Peptostreptococcus micros (Ozok et al., 2007).

- Alternatively, $\mathrm{OCl}^{-}$can react with $\mathrm{SCN}^{-}$to produce $\mathrm{HOSCN}$ (Path C) (Ashby et al., 2004). HOSCN is also produced by the SPO-catalyzed oxidation of $\mathrm{SCN}^{-}$by $\mathrm{H}_{2} \mathrm{O}_{2}$ (Ihalin et al., 2006 ; Nagy et al., 2006a). HOSCN is antimicrobial toward oral bacteria (Path D) (Clem and Klebanof, 1966; Hoogendoorn, 1976; Pruitt et al., 1979; Carlsson et al., 1983; Thomas et al., 1983, 1994b; Ellen et al., 1988; Lopatin et al., 1991; Lumikari et al., 1991; Courtois et al., 1992; Lenander-Lumikari et al., 1993, 1997; van der Hoeven and Camp, 1993; Kirstila et al., 1994; Jones et al., 1998; Fadel and Courtois, 1999, 2001; Yu et al., 2000; Ihalin et al., 2001, 2003; Korpela et al., 2002; Garcia-Graells et al., 2003; Vannini et al., 2004), but relatively non-injurious to the host (Bjoerck and Claesson, 1980; Marshall and Reiter, 1980; White et al., 1983; Carlsson et al., 1984; Carlsson, 1987).

- In addition to the reaction of $\mathrm{OCl}^{-}$with $\mathrm{SCN}^{-}$, it may react with other small molecules (Path E) to produce secondary antimicrobials [e.g., when $\mathrm{Z}$ is an amine, a cytotoxic chloramine is produced, vide infra (Abia et al., 1998; Hawkins and Davies, 1998; Hawkins et al., 2003; Davies, 2005)].

The corresponding relevance of $\mathrm{OCl}^{-} v s$. $\mathrm{OSCN}^{-}$in the oral cavity is related to the aforementioned spatial heterogeneity of the peroxidase defense systems and the corresponding chemistry. For example, the median concentration of $\mathrm{OSCN}^{-}$ in freshly collected whole saliva is $c a .10 \mu \mathrm{M}$, although the concentration increases when the saliva is incubated at $37^{\circ} \mathrm{C}$ (Thomas et al., 1980). However, direct measurement of the concentrations of these hypohalite species is problematic, because they are chemically reactive, and consequently the abundance of free ions does not necessarily reflect their significance in vivo. The fluxes of the hypohalites (the rates at which these reactive species are produced and consumed) are difficult to define in the context of the oral cavity. An even more complex issue is the relationship between these fluxes with respect to oral health and disease. This topic will be revisited in the concluding section of this review.

\section{ANTIMICROBIAL PROPERTIES OF INORGANIC COMPOUNDS}

\section{Chemical Basis of Cytotoxicity}

In contrast to antibiotics that typically target a single chemical step in a biosynthetic pathway, inorganic antimicrobials are generally biocides (they have a propensity to cause wholesale disruption of cellular processes) (Ashby, 2007; Zhu, 2007). Accordingly, these inorganic species tend to be cytotoxic, to greater or lesser degrees, to both eukaryotes and prokaryotes. Thus, any discussion of the antimicrobial properties of inorganic compounds toward infectious agents goes hand-in-hand with a related discussion of host tissue damage. It is fascinating to the author that the human body has found generally effective ways of harnessing the potentially indiscriminant cytotoxic properties of some of these compounds for defensive purposes. The cytotoxic properties of the inorganic compounds that are discussed herein can ultimately be traced to their chemistry, which can be roughly divided into two categories: (1) compounds that engage in one-electron (radical) chemistry, and (2) compounds that engage in two-electron chemistry (generally electrophilic, with eventual oxygen atom transfer). An example of one-electron chemistry is the reduction of $\mathrm{O}_{2}$ by NADPH oxidase to give $\mathrm{O}_{2}{ }^{--}$(a reaction that is carried out by PMN NADPH oxidase):

$$
\mathrm{NADPH}+2 \mathrm{O}_{2} \rightarrow \mathrm{NADP}^{+}+2 \mathrm{O}_{2}^{-{ }^{-}+\mathrm{H}^{+}}
$$

Note that NADPH is a two-electron reductant, so the chemical stoichiometry requires one NADPH to react with two oxygen molecules. However, the chemistry in fact involves one-electron steps, vis-à-vis enzyme intermediates. The reaction of $\mathrm{HOCl}$ with reduced glutathione (GSH) is an example of a two-electron (O-atom transfer) reaction (GSH is the principal cytoplasmic oxidative defense mechanism of eukaryotes, vide infra). The reaction occurs via a multistep mechanism, because the intermediate sulfenic acid (GSOH) is unstable (Nagy and Ashby, 2007; Nagy et al., 2007b):

$$
\begin{aligned}
& \mathrm{GSH}+\mathrm{HOCl} \rightarrow \mathrm{GSOH}+\mathrm{H}^{+}+\mathrm{Cl}^{-} \\
& \frac{\mathrm{GSOH}+\mathrm{GSH} \rightarrow \mathrm{GSSG}+\mathrm{H}_{2} \mathrm{O}}{2 \mathrm{GSH}+\mathrm{HOCl} \rightarrow \mathrm{GSSG}+\mathrm{H}_{2} \mathrm{O}+\mathrm{H}^{+}+\mathrm{Cl}^{-}}
\end{aligned}
$$

Note that the first equivalent of GSH that reacts with $\mathrm{HOCl}$ involves a two-electron reaction (O-atom transfer, albeit probably via the hydrolysis of a sulfenyl chloride intermediate), as does the second reaction, even though the stoichiometry of the net reaction makes it appear that GSH is a one-electron reductant. In fact, the thiyl radical (GS) is never involved in the reaction. While the distinction between one- and twoelectron processes may appear to be a superfluous detail, in fact the difference distinguishes radical processes from non-radical processes. Radicals tend to target unsaturated functional groups in lipids, nucleotides, and aromatic amino acids (Buettner, 1993). In contrast, the hypohalites tend to target the nucleophiles in proteins (Hawkins et al., 2003; Davies, 2005).

Unsaturated organic compounds (e.g., aromatic amino acids and nucleotides) are particularly susceptible to derivation by high-energy radical species; hence, nuclear damage and mutagenesis are frequently the result of one-electron chemistry 
Table 2. Major Inorganic (Reactive) Oxygen Species in the Oral Cavity

\begin{tabular}{|c|c|c|}
\hline Name & Symbol & Major Sources in the Oral Cavity \\
\hline Triplet oxygen & ${ }^{3} \mathrm{O}_{2}$ & The atmosphere \\
\hline Singlet oxygen & ${ }^{1} \mathrm{O}_{2}$ & $\begin{array}{l}\text { Peroxidase-catalyzed reactions of } \\
\mathrm{H}_{2} \mathrm{O}_{2}\end{array}$ \\
\hline Superoxide & $\mathrm{O}_{2} \cdot-$ & $\begin{array}{l}\text { NADPH reductase and leakage from } \\
\text { peroxidases }\end{array}$ \\
\hline Hydrogen peroxide & $\mathrm{H}_{2} \mathrm{O}_{2}$ & $\begin{array}{l}\text { Human dual oxidases (Duox) and } \\
\text { aerobic metabolism of glucose }\end{array}$ \\
\hline Hydroxyl radical & $\mathrm{OH}$ & $\begin{array}{l}\text { Metal-catalyzed homolysis of } \mathrm{H}_{2} \mathrm{O}_{2} \\
\text { (Fenton chemistry) }\end{array}$ \\
\hline Ozone & $\mathrm{O}_{3}$ & Catalytic decomposition of ${ }^{1} \mathrm{O}_{2}$ by $\mathrm{SlgA}$ \\
\hline
\end{tabular}

(Box et al., 2001; Marnett, 2002; Wang, 2008). Because radical chemistry tends to be very facile and comparatively indiscriminant from a chemical perspective, it is difficult for cells to mount an effective defense against radical species. In contrast, the reactivities of two-electron oxidants are typically related to the nucleophilicities of their reaction partners. Consequently, the chemistry of two-electron oxidants is usually well-defined ( $c f$. radical chemistry). Cysteine (Cys) and methionine (Met) are usually the most reactive amino acid residues toward two-electron oxidants (because sulfurcontaining compounds tend to be good nucleophiles) and are therefore often the first targets of two-electron oxidants (Hawkins et al., 2003). It is not a coincidence that the cytoplasms of eukaryotes (Meister, 1988; Fernandes et al., 2007) and many prokaryotes (Fahey et al., 1978; Smirnova and Oktyabrsky, 2005) contain high concentrations of GSH (a tripeptide containing Cys, which is used to combat oxidative stress by two-electron oxidants that operate by the aforementioned electrophilic mechanism) (Meister, 1988). It should be noted that glutathione also erects a significant defense against radical species (Sitte and Von Zglinicki, 2003; Djordjevic, 2004) (Table 2).

\section{Oxygen Derivatives}

Water $\left(\mathrm{H}_{2} \mathrm{O}\right)$ and molecular oxygen $\left(\mathrm{O}_{2}\right)$ represent limiting extremes in the oxidation state of the element oxygen $(\mathrm{O})$ in an aqueous environment. From a thermodynamic perspective, $\mathrm{O}$ exists as $\mathrm{O}_{2}$ in an overall aerobic (oxidative) environment, whereas it exists as $\mathrm{H}_{2} \mathrm{O}$ in an anaerobic (reductive) environment. The oral cavity contains microenvironments that represent these extremes. Molecular oxygen is itself "antimicrobial" toward strict anaerobes (which are routinely found in mature supragingival plaques and are abundant in subgingival plaques). However, ground-state $\mathrm{O}_{2}\left({ }^{3} \mathrm{O}_{2}\right.$, triplet oxygen, a di-radical) is not generally included among the so-called "reactive oxygen species" (ROS, Table 2). The ROS of Table 2 can be divided into the radical species $\left(\mathrm{O}_{2}{ }^{--}, \mathrm{OH}\right)$ and the "closed-shell" species $\left({ }^{1} \mathrm{O}_{2}, \mathrm{H}_{2} \mathrm{O}_{2}\right.$, and $\left.\mathrm{O}_{3}\right)$. Hydroxyl radical $(\mathrm{OH})$ is not produced in large quantities by the defensive peroxidases of the oral cavity, so it will not be further discussed here, but we refer the reader to reviews of the role of ROS in periodontal tissue destruction for more information (Waddington et al., 2000; Chapple and Matthews, 2007). In contrast, $\mathrm{O}_{2}$ - $^{-}$is pertinent in that it is produced by NADPH oxidase during neutrophilic respiratory bursts (vide supra).
Table 3. Major Inorganic (Pseudo) Hypohalites in the Oral Cavity

\begin{tabular}{|c|c|c|}
\hline Name & Symbol & Major Sources in the Oral Cavity \\
\hline Hypochlorite & $\mathrm{OCl}^{-}$ & Myelor \\
\hline Hypobromite & $\mathrm{OBr}^{-}$ & Myeloperoxidase (eosinophil peroxidase?) \\
\hline Hypothiocyanite & $\mathrm{OSCN}^{-}$ & Myeloperoxidase and salivary peroxidase \\
\hline
\end{tabular}

Despite being a radical, $\mathrm{O}_{2}{ }^{--}$is relatively chemically unreactive, and mammalian cells [and some oral bacteria (Amano et al., 1986)] contain superoxide dismutase that catalyzes the disproportionation of $\mathrm{O}_{2}^{--}$to give $\mathrm{H}_{2} \mathrm{O}_{2}$ and $\mathrm{O}_{2}$ (Packer, 2002). It is noteworthy that the conjugate acid HOO (hydroperoxyl or perhydroxyl radical) is considerably more reactive than the conjugate base $\mathrm{O}_{2}{ }^{-}$. It is conceivable that HOO $\left(\mathrm{pK}_{\mathrm{a}} c a\right.$. 4.8) (Bielski et al., 1985) plays a role in the oral cavity (e.g., during the development of acidogenic plaques). However, since $\mathrm{O}_{2}{ }^{-}$ and $\mathrm{HOO}$ are in rapid acid/base equilibrium, no distinction will be made between the two species in this review ( $c f$. $\mathrm{HOCl} v s$. $\mathrm{OCl}^{-}$, vide infra). Of the closed-shell species, only $\mathrm{H}_{2} \mathrm{O}_{2},{ }^{1} \mathrm{O}_{2}$, and $\mathrm{O}_{3}$ are relevant to our discussion.

Hydrogen peroxide is a powerful oxidant that is produced in the oral cavity by the aforementioned mechanisms (Duox, anaerobic glycolysis, disproportionation of $\mathrm{O}_{2}{ }^{--}$, etc.). Like $\mathrm{O}_{2}{ }^{--}$, $\mathrm{H}_{2} \mathrm{O}_{2}$ is relatively chemically inert. For example, it takes more than an hour for $\mathrm{H}_{2} \mathrm{O}_{2}$ to react with millimolar concentrations of Cys (Ashby and Nagy, 2006a,b). Nonetheless, $\mathrm{H}_{2} \mathrm{O}_{2}$ is cytotoxic toward mammalian cells (Ward, 1991) and most prokaryotes (Asad et al., 2004). Singlet oxygen has been detected in saliva (Takahama, 1993; Kou and Takahama, 1995; Sun et al., 2006). However, many of the reported measurements of ${ }^{1} \mathrm{O}_{2}$ remain controversial, because the probes that are used to detect it tend to be insensitive and frequently non-specific (Martinez et al., 2000). Nonetheless, it is believed that human peroxidases produce ${ }^{1} \mathrm{O}_{2}$ during their decomposition of $\mathrm{H}_{2} \mathrm{O}_{2}$ (Kanofsky, 1991). In addition to the use of therapeutic $\mathrm{O}_{3}$ (Azarpazhooh and Limeback, 2008), it has been suggested that ${ }^{1} \mathrm{O}_{2}$ is converted to $\mathrm{O}_{3}$ via an immunoglobulin-catalyzed reaction (Wentworth et al., 2000, 2002). Secretory IgA (SIgA), the most abundant immunoglobulin in saliva, is also proposed to catalyze the reaction (Uehara et al., 2006). However, the involvement of $\mathrm{O}_{3}$ remains controversial, because the probes that have been used are not specific (Kettle et al., 2004; Smith, 2004; Kettle and Winterbourn, 2005).

As a consequence of their reactive nature, all of the ROS exhibit cytotoxic properties. The relative importance of ROS as defensive agents in the oral cavity is difficult to assess, because various amounts act on microcosm plaques in diverse environments. There are likely synergisms in multi-species plaques. For example, pure cultures of oral streptococci produce $\mathrm{H}_{2} \mathrm{O}_{2}$ (they are catalase-negative), but $\mathrm{H}_{2} \mathrm{O}_{2}$ is not found in dental plaque or salivary sediment, despite streptococci being major components of their mixed bacterial populations. This is presumably due to the fast consumption of free $\mathrm{H}_{2} \mathrm{O}_{2}$ by catalase-positive species of bacteria (e.g., Neisseria, Haemophilus, Actinomyces, and Staphylococcus spp.) (Ryan and Kleinberg, 1995). Furthermore, the SPO and MPO systems of the oral cavity may protect $\mathrm{H}_{2} \mathrm{O}_{2}$-sensitive bacteria (Adamson and Carlsson, 1982). In addition to synergism between bacterial species, there are likely to be additive and/or cooperative effects 
between defensive agents. For example, there is some evidence that $\mathrm{O}_{2}^{-}$. can act synergistically with $\mathrm{OCl}^{-}$(vide infra) to induce oxidative damage (Hawkins et al., 2002) (Table 3).

\section{(Pseudo) Hypohalites}

The archetypal example of a biocide is hypochlorite $\left(\mathrm{OCl}^{-}\right.$, the principal component of household bleach). In sufficient concentrations, it is toxic to all life. Note that the reactive form of $\mathrm{OCl}^{-}$(and the other hypohalites as well) is the corresponding conjugate acid, hypohalous acid $\left(\mathrm{HOCl}, \mathrm{pK}_{\mathrm{a}}=7.4\right)$. As a neutral species, $\mathrm{HOCl}$ is presumably membrane-permeable, and therefore more cytotoxic. However, since the acid-base equilibrium between $\mathrm{HOCl}$ and $\mathrm{OCl}^{-}$is exceedingly fast, the issue of which species is actually active is academic. Under acidic conditions (and in the presence of excess $\mathrm{Cl}^{-}$), $\mathrm{OCl}^{-}$ comproportionates to give $\mathrm{Cl}_{2}$, the corresponding halogen (Adam et al., 1992). However, since the equilibrium between the hypohalites and the halogens is relatively fast, they are not generally treated as different biocides. Instead, the term "total active chlorine" is often used to describe the sum amount of hypohalous acid, hypohalite, and halogen. Furthermore, $\mathrm{HOCl} /$ $\mathrm{OCl}^{-}$are the predominant species at physiologic $\mathrm{pH}$. The relative ease with which the halides are oxidized is $\mathrm{I}^{-}>\mathrm{Br}^{-}>$ $\mathrm{Cl}^{-}$(note that $\mathrm{F}^{-}$is never oxidized in an aqueous environment), so the trend in oxidative strengths of the hypohalous acids is $\mathrm{HOCl}>\mathrm{HOBr}>>\mathrm{HOI}$. As mentioned before, $\mathrm{I}^{-}$is not abundant in most physiologic fluids, so only $\mathrm{Cl}^{-}$and $\mathrm{Br}^{-}$are relevant to this discussion.

$\mathrm{HOCl}$ and $\mathrm{HOBr}$ exhibit somewhat promiscuous reaction chemistry (the relative reactivities of $\mathrm{HOCl}$ toward proteinaceous groups are Cys $\approx$ Met $>$ cystine $\approx \mathrm{His} \approx$ $\alpha$-amino $>$ Trp $>$ Lys $>>$ Tyr $\approx$ Arg $>$ backbone amides $>$ Gln $\approx$ Asn, and a similar trend is observed for $\mathrm{HOBr}$ ) (Pattison and Davies, 2001, 2004). However, the kinetics of some of the reactions of $\mathrm{HOCl}$, and especially $\mathrm{HOBr}$, approaches the diffusion limit (Nagy et al., 2006b). As a consequence of their facile reaction, $\mathrm{HOCl}$ and $\mathrm{HOBr}$ probably exhibit poor chemical selectivity in a biological setting. In addition, secondary reactive species are produced during the reactions of $\mathrm{HOCl}$ and $\mathrm{HOBr}$ that likely contribute significantly to the overall toxicity - for example, haloamines (Grisham et al., 1984; Abia et al., 1998; Hawkins and Davies, 1998, 2003; Davies, 2005). From a chemical perspective, it is appropriate to view the reactions of $\mathrm{HOX}(\mathrm{X}=\mathrm{Cl}, \mathrm{Br})$ as a redox cascade (thermodynamically downhill) with the eventual production of chemically stable derivatives. Because of the labile nature of many of the intermediate species in such chemical cascades, and because of the fact that many of these species exhibit similar chemistries (e.g., $\mathrm{HOCl}$ and chloroamines are both electrophilic chlorinating agents, albeit with different reactivities), it is difficult to chart the consequences of the damage that occurs. Accordingly, the complexity of the chemistry precludes a definitive assignment of the antimicrobial mechanism of HOX $(\mathrm{X}=\mathrm{Cl}, \mathrm{Br})$. Nonetheless, there have been many studies of the effects of $\mathrm{HOX}(\mathrm{X}=\mathrm{Cl}, \mathrm{Br})$ on both eukaryotes (Hawkins and Davies, 2000; Hidalgo and Dominguez, 2000; Hawkins et al., 2001; Hidalgo et al., 2002; Soszynski et al., 2002; King et al., 2004) and prokaryotes (Albrich et al., 1981, 1986; Albrich and Hurst, 1982; Barrette et al., 1987, 1989; Hurst et al., 1991; Palazzolo et al., 2005). Although it is problematic to follow the reaction cascade that begins with the production of $\operatorname{HOX}(\mathrm{X}=\mathrm{Cl}, \mathrm{Br})$ in vivo, there is considerable interest in evaluation of the relevance of the $\operatorname{HOX}(\mathrm{X}=\mathrm{Cl}, \mathrm{Br})$ chemistry, particularly in the context of the host tissue damage that occurs with inflammatory disease. One approach to monitoring the chemistry of $\mathrm{HOX}(\mathrm{X}=\mathrm{Cl}, \mathrm{Br})$ in vivo is through the use of biomarkers, thermodynamically stable derivatives of HOX (X $=\mathrm{Cl}, \mathrm{Br})$. Promising biomarkers that appear to be specific for HOX $(\mathrm{X}=\mathrm{Cl}, \mathrm{Br}$ ) include 3-halotyrosines (Winterbourn and Kettle, 2000) and a sulfonamide derivative of GSH (Harwood et al., 2006).

In the field of inorganic chemistry, $\mathrm{SCN}^{-}$is called a "pseudohalide", because its reaction chemistry frequently mirrors that of the halides (Lappert and Pyszora, 1966). This is reflected in the fact that defensive peroxidases use $\mathrm{SCN}^{-}$(in addition to the halides) as a substrate. The oxidation potential of $\mathrm{SCN}^{-}$falls between those of $\mathrm{I}^{-}$and $\mathrm{Br}^{-}$. Accordingly, the chemical properties of HOSCN are most similar to those of HOI (Nagy et al., 2007a). In contrast to $\mathrm{HOCl}$ and $\mathrm{HOBr}$ (which react with a variety of functional groups), the only characterized reactions of HOSCN are with thiol moieties (which are among the most powerful nucleophiles), generally Cys and its derivatives (Ashby and Aneetha, 2004; Nimmo et al., 2007; Lemma and Ashby, 2008). Given that SH groups are apparently the targets of the HOSCN, it is important to note that roughly $40 \%$ of all enzymes are rendered ineffective by chemical agents that are reactive toward thiols (Leung-Toung et al., 2002). Thus, the destruction of functional SH moieties by HOSCN is one basis for its cytotoxicity. Importantly, the hypohalites can be interconverted through their reactions with other halides, but the process must be exothermic. For example, $\mathrm{HOCl}$ (Ashby et al., 2004) and HOBr (Nagy et al., 2006b) react with $\mathrm{SCN}^{-}$to give HOSCN and the corresponding halides, but not vice versa. In vivo, these reactions are important because they restrict the lifetimes of the more powerful (and less discriminant) hypohalites, thereby limiting their propensity to cause collateral host tissue damage. In addition, the antimicrobial $\mathrm{OSCN}^{-}$is produced in the reaction (Nagy et al., 2006a).

\section{Halides}

Fluoride is the only halide that is known to be antimicrobial without oxidation (Hamilton, 1990; Van Loveren, 1990; Marquis, 1995; Jenkins, 1999). Fluoride influences the metabolism of cariogenic and other bacteria via multiple mechanisms (Marquis et al., 2003): $\mathrm{F}^{-}$can bind directly to many enzymes (especially metalloenzymes) (Segal et al., 1968; Wever and Bakkenist, 1980; Zgliczynski et al., 1983; Thibodeau et al., 1985; Ferrari et al., 1997; Suzuki and Ohshima, 2003), thereby affecting their activities; catalase is inhibited by $\mathrm{F}^{-}$[thereby affecting the ability of $\mathrm{H}_{2} \mathrm{O}_{2}$ to kill oral bacteria (Phan et al., 2001)]; and some $\mathrm{F}^{-}$complexes of metals (e.g., $\mathrm{AlF}_{4}^{-}$and $\mathrm{BeF}_{3}^{-} \cdot \mathrm{H}_{2} \mathrm{O}$ ) can mimic phosphate, thereby affecting a variety of enzymes and regulatory phosphatases (Thongboonkerd et al., 2002). The weak-acid property of HF $\left(\mathrm{pK}_{\mathrm{a}}=3.15\right)$, which is a transmembrane proton conductor, appears to be important for inducing the glycolytic inhibition of oral bacteria that is observed at low $\mathrm{pH}$ in dental plaque (Eisenberg and Marquis, 1981) (Table 4).

\section{Nitrogen Derivatives}

After many decades of angst about nitrates in our diet and their propensity to form potentially carcinogenic $N$-nitroso derivatives (Eichholzer and Gutzwiller, 2003), there is 
mounting evidence that $\mathrm{NO}_{3}{ }^{-}$is concentrated in saliva for beneficial purposes (McKnight et al., 1999) (although the potential deleterious properties of $\mathrm{NO}_{3}^{-}$on systemic health should not be discounted). The concentration of $\mathrm{NO}_{3}{ }^{-}$in saliva is proportional to the dietary intake (Eisenbrand et al., 1980), it varies with the salivary flow rate (Granli et al., 1989), and it is influenced by smoking (Tsuchiya et al., 2002). Since $\mathrm{NO}_{3}{ }^{-}$is a relatively inert chemical species, the mechanism of antimicrobial action of $\mathrm{NO}_{3}^{-}$probably involves a redox cascade. Facultative anaerobic bacteria in the oral cavity use $\mathrm{NO}_{3}{ }^{-}$as a terminal electron acceptor ( $c f . \mathrm{O}_{2}$ for aerobic bacteria) to produce nitrite $\left(\mathrm{NO}_{2}^{-}\right)$. Acidified $\mathrm{NO}_{2}^{-}$inhibits the growth and affects the survival of cariogenic bacteria (e.g., Streptococcus mutans, Lactobacillus casei, and Actinomyces naeslundii) (Silva Mendez et al., 1999). Acidified $\mathrm{NO}_{2}^{-}$has a similar effect on periodontal bacteria (e.g., Fusobacterium nucleatum, Eikenella corrodens, and Porphyromonas gingivalis) (Allaker et al., 2001). Importantly, while the growth of periodontal bacteria is known to be inhibited by acid in the absence of $\mathrm{NO}_{2}^{-}$, there is a dose-dependent decrease in these bacteria in the presence of $\mathrm{NO}_{2}^{-}$(Allaker et al., 2001). Nitrous acid $\left(\mathrm{HNO}_{2}\right.$, $\left.\mathrm{pK}_{\mathrm{a}}=3.4\right)$ is unstable and will spontaneously disproportionate: $3 \mathrm{HNO}_{2} \rightarrow \mathrm{H}_{3} \mathrm{O}^{+}+\mathrm{NO}_{3}^{-}+2 \mathrm{NO}$. Some bacteria possess nitrite reductase (e.g., S. mutans), an enzyme that is capable of accelerating the disproportionation of $\mathrm{NO}_{2}{ }^{-}$(Choudhury et al., 2007). It appears that nitric oxide ( $\mathrm{NO}$ ) is the antimicrobial component of the $\mathrm{NO}_{3}{ }^{-} / \mathrm{NO}_{2}{ }^{-/} \mathrm{NO}$ redox cascade (Fang, 1997; Smith et al., 1999; Sato et al., 2008). The mechanism by which $\mathrm{NO}$ induces cell death is the subject of ongoing investigation. Alternative models include "oxidative stress" and "nitrosative stress" [e.g., nitrosylation of proteins without a major alteration in cellular redox state (Eu et al., 2000)]. Nitric oxide also reacts with $\mathrm{O}_{2}^{--}$to produce peroxynitrite $\left(\mathrm{ONOO}^{-}\right)$, which may also contribute to collateral host tissue damage in the oral cavity (Lohinai and Szabo, 1998; Lohinai et al., 2001; Barley et al., 2004).

\section{INTER-PERSON DIFFERENCES}

There is considerable variability in the physiological concentrations of many of the chemically stable inorganic ions that have been discussed herein. In most cases, these differences can be attributed to diets or smoking. Given the influence of these ions on the activity and function of the defensive peroxidases, there has been some interest in correlating interperson differences to oral disease. As a caveat, it is important to note that many of the relevant inorganic ions are chemically reactive, and consequently the abundance of free ions may not reflect their relevance in vivo. Some ions may exist as transient species (e.g., $\left.\mathrm{OCl}^{-}\right)$or as their conjugates with reaction partners (e.g., $\mathrm{CN}^{-}$and $\left.\mathrm{OCN}^{-}\right)$. In some cases, steadystate concentrations of reactive species may accumulate (e.g., $\mathrm{OSCN}^{-}$), but measured concentrations may not reflect the timedependent flux of such species.

\section{Thiocyanate}

The main source of $\mathrm{SCN}^{-}$in vivo is $\mathrm{CN}^{-}$, vide infra. Cyanide is principally introduced by the digestion of glucosinolatecontaining vegetables (e.g., the Brassica) (Weuffen et al., 1984). However, as a consequence of detoxification of hydrogen cyanide $\left(\mathrm{HCN}, \mathrm{pK}_{\mathrm{a}}=9.2\right.$, which is known to be present in microgram amounts per cigarette), the level of
Table 4. Major Inorganic (Reactive) Nitrogen Compounds in the Oral Cavity

Name Symbol Major Sources in the Oral cavity

$\begin{array}{lll}\text { Nitrate } & \mathrm{NO}_{3}^{-} & \text {Diet } \\ \text { Nitrite } & \mathrm{NO}_{2}^{-} & \begin{array}{l}\text { Reduction of nitrate by oral microflora } \\ \text { Nitric oxide }\end{array} \\ \mathrm{NO} & \begin{array}{l}\text { Acidification of nitrite and by enzymic } \\ \text { reactions }\end{array} \\ \text { Peroxynitrite } & \mathrm{ONOO}^{-} & \begin{array}{l}\text { Reaction of } \mathrm{NO} \text { and } \mathrm{O}_{2} \cdot- \\ \hline\end{array}\end{array}$

$\mathrm{SCN}^{-}$in smokers is considerably elevated relative to that in non-smokers. Indeed, this difference is routinely used as a biomarker for the evaluation of smoking behavior (Morabia et al., 2001). While most of the $\mathrm{CN}^{-}$that is converted to $\mathrm{SCN}^{-}$in vivo is exogenous in origin, endogenous sources contribute the sulfur vis-à-vis a multitude of reactions, some of which are enzyme-catalyzed (Wood, 1975). It has been shown that higher concentrations of $\mathrm{SCN}^{-}$in saliva can contribute to an enhancement of peroxidase activity (Tenovuo, 1976; Lamberts et al., 1984; Fonteh et al., 2005; Tahboub et al., 2005). Furthermore, as noted earlier, $\mathrm{SCN}^{-}$is a potent sequestering agent for some reactive oxidants (Ashby et al., 2004; Nagy et al., 2006b). Accordingly, one might conclude that higher $\mathrm{SCN}^{-}$ (either as a consequence of diet or through smoking) should result in a suppression of oral disease. However, while smokers have elevated $\mathrm{SCN}^{-}$and $\mathrm{OSCN}^{-}$levels in their saliva, no corresponding correlation with dental caries has been observed (Lamberts et al., 1984). Interestingly, although there is not an association between smoking and caries among adults, there is a positive correlation between environmental (second-hand) tobacco smoke and primary tooth caries in children (Shenkin et al., 2004). In contrast to caries, there is a strong correlation between smoking (and consequently $\mathrm{SCN}^{-}$levels) and some periodontal diseases (Rivera-Hidalgo, 2003). Since there is also a correlation between smoking and $\mathrm{SCN}^{-}$levels in $\mathrm{GCF}$, $\mathrm{SCN}^{-}$levels presumably exhibit a positive correlation with periodontal diseases. However, $\mathrm{SCN}^{-}$is only one of many inorganic and organic chemicals that are elevated by smoking. Two other inorganic ions are $\mathrm{CN}^{-}$and cyanate $\left(\mathrm{OCN}^{-}\right)$, vide infra.

\section{Cyanide}

It addition to dietary sources (e.g., cyanogenic glucosides, vide supra) and tobacco smoke, other sources of $\mathrm{CN}^{-}$in vivo include micro-organisms (in particular certain pseudomonads) and industrial exposure (e.g., vis-à-vis organonitriles) (Wong-Chong et al., 2006). There appear to be no studies that have determined the normal concentration of $\mathrm{CN}^{-}$in the fluids of the oral cavity. However, there is a statistical correlation between blood and salivary $\mathrm{SCN}^{-}$levels (Tsuge et al., 2000). As noted earlier, the concentrations of $\mathrm{SCN}^{-}$in physiological fluids (including GCF and saliva) in smokers are substantially higher than those for non-smokers. Therefore, it follows that the oral cavity is exposed to higher concentrations of $\mathrm{CN}^{-}$for smokers compared with non-smokers. HCN contributes to the loss of peroxidase activity in saliva upon exposure to cigarette smoke (Klein et al., 2003). This is due to the strong complexation of $\mathrm{CN}^{-}$to the iron-active sites of the peroxidases (fundamentally the same mechanism that renders $\mathrm{CN}^{-}$toxic to the respiratory system 
$v i s-\grave{a}$-vis the complexation of hemoglobin and myoglobin). It is noteworthy that there is no correlation between $\mathrm{CN}^{-}$in plasma and the concentration of $\mathrm{HCN}$ in breath (Lundquist et al., 1988). Furthermore, the concentrations of HCN measured in breath are higher than expected for blood concentrations, which suggested a local production of $\mathrm{HCN}$ in the oropharynx. Under some circumstances, $\mathrm{OSCN}^{-}$can decompose to give $\mathrm{CN}^{-}$(Aune and Thomas, 1977). While the major cyanide-derived product of the decomposition of $\mathrm{OSCN}^{-}$is $\mathrm{OCN}^{-}$, we have observed the formation of substantial amounts of $\mathrm{CN}^{-}$during the hydrolysis of thiocyanogen $\left[(\mathrm{SCN})_{2}\right.$, analogous to a halogen] at neutral $\mathrm{pH}$ (unpublished observations). It is conceivable that the latter reaction is the source of $\mathrm{HCN}$ in breath.

\section{Cyanate}

Cyanate $\left(\mathrm{OCN}^{-}\right)$is produced by the oxidation of $\mathrm{CN}^{-}$. Thus, $\mathrm{OCN}^{-}$levels are higher in smokers. Under some conditions, the decomposition of $\mathrm{OSCN}^{-}$also produces $\mathrm{OCN}^{-}$(Oram and Reiter, 1966). MPO is inhibited by $\mathrm{OCN}^{-}$(Qian et al., 1997). The inhibition could be caused by heme binding of $\mathrm{OCN}^{-}$(thereby blocking the active site) or by carbamylation of the protein by $\mathrm{OCN}^{-}$. It is noteworthy that the functional impairment of proteins through carbamylation by $\mathrm{OCN}^{-}$is thought to promote human inflammatory diseases (Wang et al., 2007). However, the possible relevance of carbamylation in the oral cavity has not been investigated. There is very limited information available regarding the effect of $\mathrm{OCN}^{-}$on oral bacteria (Morita, 1977).

\section{Fluoride}

In the absence of supplementation by fluoride-containing dentrifices, the concentration of $\mathrm{F}^{-}$in saliva (and presumably GCF) is somewhat lower than the concentration in plasma (Oliveby et al., 1989). The normal concentration of $\mathrm{F}^{-}$in saliva (ca. $1 \mu \mathrm{M})$ can increase markedly after the ingestion of $\mathrm{F}^{-}$, and change dynamically thereafter (Dawes and Weatherell, 1990). An early study that used PMN granules (and not isolated enzymes) suggested that $\mathrm{F}^{-}$does not influence the activity of MPO (which was determined by measurement of the iodination of zymosan) (Gabler and Leong, 1980). In contrast, the same study reported that the iodination of zymosan was inhibited by $\mathrm{F}^{-}$for intact PMNs (Gabler and Leong, 1980). However, the $\mathrm{pH}$-dependent competitive inhibition of isolated LPO (Segal et al., 1968; Thibodeau et al., 1985) and MPO (Zgliczynski et al., 1983; van den Abbeele et al., 1992) by $\mathrm{F}^{-}$has been demonstrated. For example, half of the activity of bovine LPO occurs for $<0.05 \mathrm{mM}$ at $\mathrm{pH} 4,0.3 \mathrm{mM}$ at $\mathrm{pH}$, $4.0 \mathrm{mM}$ at $\mathrm{pH} 6$, and greater than $10 \mathrm{mM}$ at $\mathrm{pH} \mathrm{7}$, as assayed with $5 \mathrm{mM} \mathrm{I}^{-}$and $150 \mu \mathrm{M} \mathrm{H}_{2} \mathrm{O}_{2}$ (Thibodeau et al., 1985). It is noteworthy that SPO was found to have lower $\mathrm{pH}$ optima relative to LPO, but it also was inhibited by $\mathrm{F}^{-}$at sufficiently low pH (Thibodeau et al., 1985). A similar inhibitory effect of $\mathrm{F}^{-}$on peroxidase activity has been observed in whole saliva (Thibodeau et al., 1985; Hannuksela et al., 1994; van den Abbeele et al., 1995). These observations suggest that $\mathrm{F}^{-}$in dental plaque may inhibit the peroxidase defense system. However, when $\mathrm{F}^{-}$and $\mathrm{OSCN}^{-}$are added simultaneously at $\mathrm{pH}$ 5.0, an additive effect of growth inhibition of S. mutans was observed (Lenander-Lumikari et al., 1997). Thus, the small inhibitory effect of $\mathrm{F}^{-}$on the defensive peroxidase systems of the oral cavity may be offset by the combinatorial antimicrobial effects of $\mathrm{F}^{-}$and $\mathrm{OSCN}^{-}$.

\section{Nitrate and Nitrite}

Basal levels of $\mathrm{NO}_{3}{ }^{-}$in saliva are 10-20 times those found in plasma (and presumably GCF) (Duncan et al., 1995; Benjamin and McKnight, 1999; Pannala et al., 2003; Lundberg et al., 2004). For the average diet in the US, $c a$. $80 \%$ of dietary $\mathrm{NO}_{3}{ }^{-}$ is derived from vegetables (White, 1975). Cured meats, for example, typically represent a minor source of $\mathrm{NO}_{3}{ }^{-}$in most diets. However, urinary, plasma, and saliva $\mathrm{NO}_{3}{ }^{-}$concentrations increase markedly after the consumption of a high-nitrate meal (Pannala et al., 2003). The maximum concentration is achieved within a few hours following the meal, and $\mathrm{NO}_{3}{ }^{-}$concentrations return to basal levels within 24 hours. The amount of $\mathrm{NO}_{3}{ }^{-}$that is excreted in the urine following the consumption of a highnitrate meal suggests that the majority of urinary $\mathrm{NO}_{3}{ }^{-}$can be accounted for in dietary sources (Pannala et al., 2003). In contrast to $\mathrm{NO}_{3}{ }^{-}$, an increase in $\mathrm{NO}_{2}^{-}$is observed in saliva only after the consumption of a high-nitrate meal (Pannala et al., 2003), which is consistent with the fact that $\mathrm{NO}_{3}{ }^{-}$is metabolized to $\mathrm{NO}_{2}^{-}$by bacterial flora on the posterior surface of the tongue in rat models (Duncan et al., 1995). Nitrite has been shown to enhance the reactivity of LPO (Reszka et al., 1997, 1998, 1999; van der Vliet et al., 1997; Gebicka, 1999; Bruck et al., 2001) and MPO (Burner et al., 2000). In addition to an enhancement in the rate of catalysis by $\mathrm{NO}_{2}^{-}$, it has been suggested that $\mathrm{NO}_{3}{ }^{-}$reduces acidity in the oral cavity ( $\mathrm{Li}$ et al., 2007). Thus, $\mathrm{NO}_{2}^{-}$and $\mathrm{NO}_{3}^{-}$may play a beneficial role in the oral cavity. We note that there has apparently been no attempt to correlate oral health with inter-person differences in nitratereducing capacity.

\section{PEROXIDE TOXICITY AND PEROXIDASE FUNCTION}

At sufficient concentrations, $\mathrm{H}_{2} \mathrm{O}_{2}$ is cytotoxic to mammalian cell lines, including human epithelial cells (Mattana et al., 1992) and gingival fibroblasts (Tenovuo and Larjava, 1984; Tipton et al., 1995a). While $\mathrm{H}_{2} \mathrm{O}_{2}$ is a relatively chemically inert molecule, its homolysis to give $\mathrm{OH}$ radicals is catalyzed by transition metals, particularly iron, in a reaction that is referred to as Fenton chemistry (Prousek, 2007). Much of the cytotoxicity of $\mathrm{H}_{2} \mathrm{O}_{2}$ is attributed to Fenton chemistry (Winterbourn, 1995). In the presence of $\mathrm{SCN}^{-}$, the $\mathrm{LPO}$ system protects cultured mammalian cells against $\mathrm{H}_{2} \mathrm{O}_{2}$ toxicity (Hänström et al., 1983). This is consistent with the observation that $\mathrm{OSCN}^{-}$is not toxic toward mammalian cells (Bjoerck and Claesson, 1980; Marshall and Reiter, 1980; White et al., 1983; Carlsson et al., 1984; Carlsson, 1987). It has been previously suggested that one of the important roles of human peroxidases is to detoxify $\mathrm{H}_{2} \mathrm{O}_{2}$ to prevent host tissue damage (Carlsson, 1987; Tipton et al., 1995b). Since many prokaryotes are also sensitive to $\mathrm{H}_{2} \mathrm{O}_{2}$, the human peroxidase systems may also protect certain bacteria by sequestering $\mathrm{H}_{2} \mathrm{O}_{2}$. However, the $\mathrm{OSCN}^{-}$that is produced is inhibitory toward most bacteria. Consequently, it is difficult to envisage the net effect of $\mathrm{H}_{2} \mathrm{O}_{2}$ sequestration vs. OSCN ${ }^{-}$on bacterial growth (Fig. 2).

\section{THE ANTIMICROBIAL DEPLETION MODEL}

The efficacy of chemically reactive antimicrobial agents can be diffusion-limited. This is one (but certainly not the only) explanation for the greater sensitivity of planktonic cultures to chemically reactive antimicrobials (Stewart, 1994; 
Stewart and Raquepas, 1995; Dodds et al., 2000; Stewart et al., 2001, 2004; Hunt et al., 2005). Planktonic cultures are generally agitated, and consequently fluid flows by a convection mechanism that transports solutes rapidly. In contrast, fluid flow in biofilms can be highly restricted. For thick biofilms, such as the plaques of the oral cavity, the primary mechanism of solute transport is diffusion (unagitated flow). For highly reactive molecules such

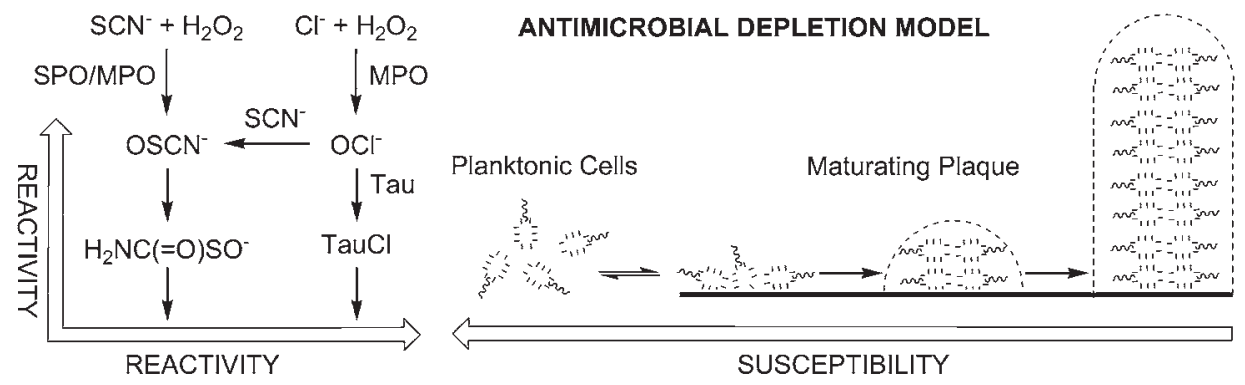

Figure 2. Relationship between the reactivities of inorganic defense factors of the oral cavity and maturation of plaque biofilms. The penetrability of the hypohalites and their derivatives is inversely related to their reactivities and the extent of maturation of the biofilm. See the text for a discussion of the possibility that the defensive factors could be generated within biofilms. as $\mathrm{HOCl}$, which also exhibit promiscuous reaction chemistry, the biomass of plaques offers a formidable barrier to penetration. While $\mathrm{HOCl}$ is an extremely effective antimicrobial toward planktonic cell suspensions, it is a comparatively inefficient killing agent with respect to biofilms. For example, a 600-fold increase in concentration of $\mathrm{HOCl}$ (per cell) is required to kill certain biofilms of Staphylococcus aureus, compared with planktonic cultures of the same species (Luppens et al., 2002). More chemically selective antimicrobials, e.g., $\mathrm{OSCN}^{-}$, are more likely to penetrate thick biofilms before reacting. The relationship between chemical reactivity of the antimicrobial and biofilm penetrability forms the basis of the Antimicrobial Depletion Model (Fig. 2). There is presumably an inverse relationship between penetrability with respect to the antimicrobial reactivity. However, penetrability, of course, is not the only factor that determines the efficacy of the antimicrobial: $\mathrm{OSCN}^{-}$ is generally considered to be bacteriostatic, whereas $\mathrm{OCl}^{-}$is bactericidal. But, as mentioned before, there is a tradeoff for the higher reactivity/poorer selectivity of $\mathrm{OCl}^{-}$: the potential of host tissue damage. In the oral cavity, it may be advantageous for the body to use a collection of antimicrobials that exhibit a continuum of reactivity. Thus, complementing $\mathrm{HOCl}$ is taurine chloroamine ( $\mathrm{TauCl})$, a less reactive (Carr et al., 2001) and more selective (Peskin and Winterbourn, 2006) electrophilic chlorinating agent that may play a role in host defense in the oral cavity (Woldring, 1955; Mainnemare et al., 2004). Similarly, we have discovered a corresponding less-reactive derivative of $\mathrm{OSCN}^{-}$, thiocarbamate-S-oxide $\left[\mathrm{H}_{2} \mathrm{NC}(=\mathrm{O})\right.$ -

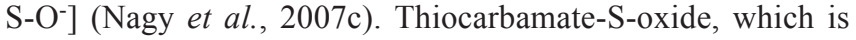
formed by the hydrolysis of $\mathrm{OSCN}^{-}$, is one of the chemical species formed during the redox cascade that results in the decomposition of $\mathrm{OSCN}^{-}$(Nagy et al., 2007c). Recently, we have learned that $\mathrm{H}_{2} \mathrm{NC}(=\mathrm{O})-\mathrm{S}_{-} \mathrm{O}^{-}$reacts with thiols via a mechanism that is analogous to the one that is observed for $\mathrm{OSCN}^{-}$, albeit with slower kinetics (unpublished observations). While the effect of $\mathrm{H}_{2} \mathrm{NC}(=\mathrm{O})-\mathrm{S}-\mathrm{O}^{-}$on bacterial physiology remains to be investigated, its discovery demonstrates that there is much to be learned about the inorganic antimicrobials produced by the defensive peroxidases.

The Antimicrobial Depletion Model does not explicitly include the possibility that defensive peroxidases might generate hypohalites within the biofilms, thereby obviating the need for reactive species to diffuse into biofilms. We note that the production of acid in salivary sediment is more effectively inhibited when $\mathrm{OSCN}^{-}$is produced by sediment-

bound peroxidases than when salivary sediment is treated with exogenous $\mathrm{OSCN}^{-}$(Tenovuo, 1979). However, salivary sediment has a larger buffer capacity and "organic load" (e.g., non-viable cells) than plaque (Singer et al., 1983), so it is not clear whether the penetration of $\mathrm{OSCN}^{-}$into plaque is comparably diffusion-limited. The production of hypohalites from within plaques requires the transport of the components of peroxidase systems into the biofilm: peroxidase, (pseudo) halide, and $\mathrm{H}_{2} \mathrm{O}_{2}$. Relevant to the issue of diffusion of peroxidases into plaques, it has been previously observed that LPO binds to $S$. mutans (LPO is a cationic protein, and the outer membranes of Gram-positive bacteria are negatively charged) (Pruitt et al., 1979). While cell-bound LPO remains catalytically active initially, it is eventually inactivated (Pruitt et al., 1979). Thus, the electrostatic attraction of the peroxidases for cells and the subsequent inactivation of the cell-bound enzyme may preclude the generation of hypohalites within a thick plaque (Pruitt et al., 1979). With regard to the availabilities of the other components of the peroxidase defense systems, it is probable that the concentrations of the (pseudo)halides in plaques reflect their concentrations in the physiologic fluids that surround them (i.e., saliva or GCF), but it was noted earlier that $\mathrm{H}_{2} \mathrm{O}_{2}$ has not been found in dental plaques (Ryan and Kleinberg, 1995). The issue of whether or not the human defensive peroxidase systems are active in thick plaques remains unresolved.

\section{CONCLUSION}

The distinctive chemical environments of the supragingival and subgingival regions impose restrictions on the human peroxidase defense strategies of the oral cavity (e.g., vis-à-vis substrate bioavailability). Inter-person differences may also influence the function and activity of the enzymes and the chemistry of the reactive species that the enzymes generate. The abilities of the defensive agents produced by the peroxidase systems to differentiate between host tissues and the microbiota are an unsettled issue. Oral diseases are accompanied by microbial shifts of dental plaque, so a more subtle issue is whether these agents differentiate between commensal and pathogenic microbiota. While it seems likely that ecological principles, as in the March ecological hypothesis (Marsh, 2003), can be applied to explain microbial shifts, it is not yet clear what ecological pressures are inducing these microbial shifts, nor is the root cause of host tissue damage completely 
clear. For dental caries in enamel, damage is clearly a direct effect of the plaque. In dentinal and root caries, some host response may be involved (as in periodontitis). The microbial shift during cariogenesis is toward acidogenic and acid-tolerant Gram-positive bacteria, which displace the acid-sensitive commensal microbiota that are associated with intact tooth tissues. Since supragingivally generated $\mathrm{OSCN}^{-}$targets Grampositive bacteria (S. mutans may be particularly affected), it is possible that $\mathrm{OSCN}^{-}$may be important in modifying plaque cariogenicity. Other important health-maintaining functions of $\mathrm{OSCN}^{-}$may also occur, such as restricting supragingival intra-oral cross-infection by periodontal pathogens. During the development of periodontal diseases, an increase in diseaseassociated anaerobes occurs in conjunction with increased inflammation. The inflammatory response is primarily due to antigens that have been introduced by the bacteria. It is unclear whether the inflammation is due to changes in the antigens introduced by the microbial shift (Lamster and Novak, 1992), or whether the microbial shift has been induced by the inflammatory response, or both (Dalwai et al., 2006). Is the host tissue damage of periodontal diseases solely the consequence of host mediators (e.g., $\mathrm{HOCl})$, or is there direct attack by bacterial virulence factors such as proteolytic enzymes? Definitive answers to these questions are critical for a rational approach to combating oral disease-Does one treat the inflammation, or does one target pathogenic bacteria, or is it necessary to treat both (Van Dyke, 2007)? Other risk factors being similar, is inter-individual variation in peroxidase activity a key factor in determining why some people develop oral disease and others do not? Whether inter-person differences between the inorganic chemistry of the oral cavity contribute to oral diseases is a topic that deserves further attention.

\section{ACKNOWLEDGMENT}

The author is supported by Public Health Service grant R21 DE016889-01A2 from the National Institute of Dental and Craniofacial Research.

\section{REFERENCES}

Abia L, Armesto XL, Canle L M, Garcia MV, Santaballa JA (1998). Oxidation of aliphatic amines by aqueous chlorine. Tetrahedron 54:521-530.

Adam LC, Fabian I, Suzuki K, Gordon G (1992). Hypochlorous acid decomposition in the pH 5-8 region. Inorg Chem 31:3534-3541.

Adamson M, Carlsson J (1982). Lactoperoxidase and thiocyanate protect bacteria from hydrogen peroxide. Infect Immun 35:20-24.

Albrich JM, Hurst JK (1982). Oxidative inactivation of Escherichia coli by hypochlorous acid. Rates and differentiation of respiratory from other reaction sites. FEBS Lett 144:157-161.

Albrich JM, McCarthy CA, Hurst JK (1981). Biological reactivity of hypochlorous acid: implications for microbicidal mechanisms of leukocyte myeloperoxidase. Proc Natl Acad Sci USA 78:210-214.

Albrich JM, Gilbaugh JH 3rd, Callahan KB, Hurst JK (1986). Effects of the putative neutrophil-generated toxin, hypochlorous acid, on membrane permeability and transport systems of Escherichia coli. $J$ Clin Invest 78:177-184.

Allaker RP, Mendez LSS, Hardie JM, Benjamin N (2001). Antimicrobial effect of acidified nitrite on periodontal bacteria. Oral Microbiol Immunol 16:253-256.

Amano A, Tamagawa H, Shizukuishi S, Tsunemitsu A (1986). Superoxide dismutase, catalase and peroxidases in oral anaerobic bacteria. J Osaka Univ Dent Sch 26:187-192.

Anttonen T, Tenovuo J (1981). Crevicular thiocyanate and iodide ions: cofactors of the antimicrobial peroxidase system in leucocytes. Proc Finn Dent Soc 77:318-323.

Arnhold J, Monzani E, Furtmueller PG, Zederbauer M, Casella L, Obinger C (2006). Kinetics and thermodynamics of halide and nitrite oxidation by mammalian heme peroxidases. Eur J Inorg Chem 19:3801-3811.

Asad NR, Asad LMBO, Bonacossa de Almeida CE, Felzenszwalb I, Cabral-Neto JB, Leitão AC (2004). Several pathways of hydrogen peroxide action that damage the E. coli genome. Genet Mol Biol 27:291-303.

Ashby MT (2007). Where old biocides meet new biocides: hypohalite defense factors of the human oral cavity. ACS Symposium Series (New Biocides Development) 967:269-290.

Ashby MT, Aneetha H (2004). Reactive sulfur species: aqueous chemistry of sulfenyl thiocyanates. J Am Chem Soc 126:1021610217.

Ashby MT, Nagy P (2006a). On the kinetics and mechanism of the reaction of cysteine and hydrogen peroxide in aqueous solution. Comments. J Pharm Sci 95:15-18.

Ashby MT, Nagy P (2006b). Revisiting a proposed kinetic model for the reaction of cysteine and hydrogen peroxide via cysteine sulfenic acid. Int $J$ Chem Kinet 39:32-38.

Ashby MT, Carlson AC, Scott MJ (2004). Redox buffering of hypochlorous acid by thiocyanate in physiologic fluids. $J \mathrm{Am}$ Chem Soc 126:15976-15977.

Aune TM, Thomas EL (1977). Accumulation of hypothiocyanite ion during peroxidase-catalyzed oxidation of thiocyanate ion. Eur $J$ Biochem 80:209-214.

Azarpazhooh A, Limeback H (2008). The application of ozone in dentistry: a systematic review of literature. $J$ Dent 36:104-116.

Azuma M (2006). Fundamental mechanisms of host immune responses to infection. J Periodontal Res 41:361-373.

Baker PJ, Roopenian DC (2002). Genetic susceptibility to chronic periodontal disease. Microbes Infect 4:1157-1167.

Barley RDC, Pollock S, Shallow MC, Peters E, Lam EWN (2004). Tobacco-related-compound-induced nitrosative stress injury in the hamster cheek pouch. J Dent Res 83:903-908.

Barnard D, Davies J, Figdor D (1996). Susceptibility of Actinomyces israelii to antibiotics, sodium hypochlorite and calcium hydroxide. Int Endod J 29:320-326.

Barrette WC Jr, Albrich JM, Hurst JK (1987). Hypochlorous acidpromoted loss of metabolic energy in Escherichia coli. Infect Immun 55:2518-2525.

Barrette WC Jr, Hannum DM, Wheeler WD, Hurst JK (1989). General mechanism for the bacterial toxicity of hypochlorous acid: abolition of ATP production. Biochemistry 28:9172-9178.

Benjamin N, McKnight G (1999). Metabolism of nitrate in humansimplications for nitrate intake. $R$ Soc Chem 237(Spec Pub):281288.

Bergström J (2004). Tobacco smoking and chronic destructive periodontal disease. Odontology 92:1-8.

Bielski BHJ, Cabelli DE, Arudi RL, Ross AB (1985). Reactivity of perhydroxyl/superoxide radicals in aqueous solution. J Phys Chem Ref Data 14:1041-1100.

Bjoerck L, Claesson O (1980). Correlation between concentration of hypothiocyanate and antibacterial effect of the lactoperoxidase system against Escherichia coli. J Dairy Sci 63:919-922.

Box HC, Dawidzik JB, Budzinski EE (2001). Free radical-induced double lesions in DNA. Free Radic Biol Med 31:856-868.

Briseno BM, Wirth R, Hamm G, Standhartinger W (1992). Efficacy of different irrigation methods and concentrations of root canal irrigation solutions on bacteria in the root canal. Endod Dent Traumatol 8:6-11.

Bruck TB, Fielding RJ, Symons MCR, Harvey PJ (2001). Mechanism of nitrite-stimulated catalysis by lactoperoxidase. Eur J Biochem 268:3214-3222. 
Buettner GR (1993). The pecking order of free radicals and antioxidants: lipid peroxidation, $\alpha$-tocopherol, and ascorbate. Arch Biochem Biophys 300:535-543.

Burner U, Furtmuller PG, Kettle AJ, Koppenol WH, Obinger C (2000). Mechanism of reaction of myeloperoxidase with nitrite. $J$ Biol Chem 275:20597-20601.

Calas P, Rochd T, Druilhet P, Azais JM (1998). In vitro adhesion of two strains of Prevotella nigrescens to the dentin of the root canal: the part played by different irrigation solutions. J Endod 24:112115.

Carlsson J (1987). Salivary peroxidase: an important part of our defense against oxygen toxicity. J Oral Pathol 16:412-416.

Carlsson J, Iwami Y, Yamada T (1983). Hydrogen peroxide excretion by oral streptococci and effect of lactoperoxidase-thiocyanatehydrogen peroxide. Infect Immun 40:70-80.

Carlsson J, Edlund MB, Hänstroem L (1984). Bactericidal and cytotoxic effects of hypothiocyanite-hydrogen peroxide mixtures. Infect Immun 44:581-586.

Carr AC, Hawkins CL, Thomas SR, Stocker R, Frei B (2001). Relative reactivities of N-chloramines and hypochlorous acid with human plasma constituents. Free Radic Biol Med 30:526-536.

Carson KR, Goodell GG, McClanahan SB (2005). Comparison of the antimicrobial activity of six irrigants on primary endodontic pathogens. J Endod 31:471-473.

Chapple IL, Matthews JB (2007). The role of reactive oxygen and antioxidant species in periodontal tissue destruction. Periodontol 2000 43:160-232.

Choudhury T, Sato EF, Inoue M (2007). Nitrite reductase in Steptoccocus mutans plays a critical role in the survival of this pathogen in oral cavity. Oral Microbiol Immunol 22:384-389.

Clem WH, Klebanof SJ (1966). Inhibitory effect of saliva on glutamic acid accumulation by Lactobacillus acidophilus and role of lactoperoxidase-thiocyanate system. J Bacteriol 91:1848-1853.

Courtois P, Majerus P, Labbe M, van den Abbeele A, Yourassowsky E, Pourtois M (1992). Susceptibility of anaerobic microorganisms to hypothiocyanite produced by lactoperoxidase. Acta Stomatol Belg 89:155-162.

D'Arcangelo C, Varvara G (1998). A comparative in-vitro study of the bactericidal efficacy of sodium hypochlorite and chlorhexidine gluconate plus cetrimide on root canal anaerobic bacterial flora. Minerva Stomatol 47:381-386.

D’Arcangelo C, Di Nardo Di Maio F, Varvara G (1998). Alphahemolytic Streptococci and root canal irrigants. An evaluation of the bactericidal efficacy of sodium hypochlorite and chlorhexidine gluconate plus cetrimide. Minerva Stomatol 47:367-371.

Dahlgren C, Karlsson A (1999). Respiratory burst in human neutrophils. J Immunol Methods 232:3-14.

Dalwai F, Spratt DA, Pratten J (2006). Modeling shifts in microbial populations associated with health or disease. Appl Environ Microbiol 72:3678-3684.

Davies MJ (2005). The oxidative environment and protein damage. Biochim Biophys Acta 1703:93-109.

Dawes C, Weatherell JA (1990). Kinetics of fluoride in the oral fluids. $J$ Dent Res 69(Spec Iss):638-644.

Djordjevic VB (2004). Free radicals in cell biology. Int Rev Cytol 237:57-89.

Dodds MG, Grobe KJ, Stewart PS (2000). Modeling biofilm antimicrobial resistance. Biotechnol Bioeng 68:456-465.

Donko A, Peterfi Z, Sum A, Leto T, Geiszt M (2005). Dual oxidases. Phil Trans R Soc London B: Biol Sci 360:2301-2308.

Duncan C, Dougall H, Johnston P, Green S, Brogan R, Leifert C, et al. (1995). Chemical generation of nitric oxide in the mouth from the enterosalivary circulation of dietary nitrate. Nat Med 1:546-551.

Ebersole JL (2003). Humoral immune responses in gingival crevice fluid: local and systemic implications. Periodontol 2000 31:135166.
Eichholzer M, Gutzwiller F (2003). Dietary nitrates, nitrites and $\mathrm{N}$-nitroso compounds and cancer risk with special emphasis on the epidemiological evidence (abstract). In: Food safety: contaminants and toxins. Zürich, Switzerland: CABI Publishing, pp. 217-234.

Eisenberg AD, Marquis RE (1981). Enhanced transmembrane proton conductance in Streptococcus mutans gs-5 due to ionophores and fluoride. Antimicrob Agents Chemother 19:807-812.

Eisenbrand G, Spiegelhalder B, Preussmann R (1980). Nitrate and nitrite in saliva. Oncology 37:227-231.

Ellen RP, Schwarz-Faulkner S, Grove DA (1988). Coaggregation among periodontal pathogens, emphasizing Bacteroides gingivalisActinomyces viscosus cohesion on a saliva-coated mineral surface. Can J Microbiol 34:299-306.

Eu JP, Liu L, Zeng M, Stamler JS (2000). An apoptotic model for nitrosative stress. Biochemistry 39:1040-1047.

Fadel M, Courtois P (1999). Effect of peroxidase-generated hypothiocyanite on the survival rate of Porphyromonas gingivalis NCTC 11834. Med Sci Res 27:667-669.

Fadel M, Courtois P (2001). Inhibitory effect of lactoperoxidasegenerated hypothiocyanite upon black pigmented anaerobe growth. Int J Mol Med 8:59-62.

Fahey RC, Brown WC, Adams WB, Worsham MB (1978). Occurrence of glutathione in bacteria. $J$ Bacteriol 133:1126-1129.

Fang FC (1997). Mechanisms of nitric oxide-related antimicrobial activity. J Clin Invest 99:2818-2825.

Fang M, Chen JH, Xu XL, Yang PH, Hildebrand HF (2006). Antibacterial activities of inorganic agents on six bacteria associated with oral infections by two susceptibility tests. Int $J$ Antimicrob Agents 27:513-517.

Featherstone JD (2000). The science and practice of caries prevention. $J$ Am Dent Assoc 131:887-899.

Fernandes PN, Mannarino SC, Silva CG, Pereira MD, Panek AD, Eleutherio ECA (2007). Oxidative stress response in eukaryotes: effect of glutathione, superoxide dismutase and catalase on adaptation to peroxide and menadione stresses in Saccharomyces cerevisiae. Redox Rep 12:236-244.

Ferrari RP, Ghibaudi EM, Traversa S, Laurenti E, De Gioia L, Salmona M (1997). Spectroscopic and binding studies on the interaction of inorganic anions with lactoperoxidase. J Inorg Biochem 68:17-26.

Ferreira CM, Bonifacio KC, Froner IC, Ito IY (1999). Evaluation of the antimicrobial activity of three irrigating solutions in teeth with pulpal necrosis. Braz Dent $J$ 10:15-21.

Fonteh FA, Grandison AS, Lewis MJ (2005). Factors affecting lactoperoxidase activity. Int J Dairy Technol 58:233-236.

Fragoso MA, Fernandez V, Forteza R, Randell SH, Salathe M, Conner GE (2004). Transcellular thiocyanate transport by human airway epithelia. J Physiol 561(Pt 1):183-194.

Furtmueller PG, Burner U, Obinger C (1998). Reaction of myeloperoxidase Compound I with chloride, bromide, iodide, and thiocyanate. Biochemistry 37:17923-17930.

Gabler WL, Leong PA (1980). Effect of fluoride on polymorphonuclear leukocyte myeloperoxidase. J Dent Res 59:135.

Garcia-Graells C, Van Opstal I, Vanmuysen SCM, Michiels CW (2003). The lactoperoxidase system increases efficacy of highpressure inactivation of foodborne bacteria. Int $J$ Food Microbiol 81:211-221.

Gebicka L (1999). Kinetic studies on the oxidation of nitrite by horseradish peroxidase and lactoperoxidase. Acta Biochim Pol 46:919-927.

Geiszt M, Witta J, Baffi J, Lekstrom K, Leto TL (2003). Dual oxidases represent novel hydrogen peroxide sources supporting mucosal surface host defense. FASEB J 17:1502-1504.

Genco RJ (1996). Current view of risk factors for periodontal diseases. $J$ Periodontol 67(10 Suppl):1041S-1049S.

Gerson C, Sabater J, Scuri M, Torbati A, Coffey R, Abraham JW, et al. (2000). The lactoperoxidase system functions in bacterial 
clearance of airways. Am J Respir Cell Mol Biol 22:665-671.

Granli T, Dahl R, Brodin P, Bockman OC (1989). Nitrate and nitrite concentrations in human saliva: variations with salivary flow-rate. Food Chem Toxicol 27:675-680.

Graves DT, Jiang Y, Genco C (2000). Periodontal disease: bacterial virulence factors, host response and impact on systemic health. Curr Opin Infect Dis 13:227-232.

Grisham MB, Jefferson MM, Melton DF, Thomas EL (1984). Chlorination of endogenous amines by isolated neutrophils. Ammonia-dependent bactericidal, cytotoxic, and cytolytic activities of the chloramines. J Biol Chem 259:10404-10413.

Hamilton IR (1990). Biochemical effects of fluoride on oral bacteria. $J$ Dent Res 69(Spec Iss):660-667.

Hannuksela S, Tenovuo J, Roger V, Lenander-Lumikari M, Ekstrand J (1994). Fluoride inhibits the antimicrobial peroxidase systems in human whole saliva. Caries Res 28:429-434.

Hänström L, Johansson A, Carlsson J (1983). Lactoperoxidase and thiocyanate protect cultured mammalian cells against hydrogen peroxide toxicity. Med Biol 61:268-274.

Harwood DT, Kettle AJ, Winterbourn CC (2006). Production of glutathione sulfonamide and dehydroglutathione from gsh by myeloperoxidase-derived oxidants and detection using a novel lc-ms/ms method. Biochem J 399:161-168.

Hawkins CL, Davies MJ (1998). Hypochlorite-induced damage to proteins: formation of nitrogen-centered radicals from lysine residues and their role in protein fragmentation. Biochem $J 332(\mathrm{Pt}$ 3):617-625.

Hawkins CL, Davies MJ (2000). Hypochlorite-induced damage to red blood cells. Evidence for the formation of nitrogen-centered radicals. Redox Rep 5:57-59.

Hawkins CL, Brown BE, Davies MJ (2001). Hypochlorite- and hypobromite-mediated radical formation and its role in cell lysis. Arch Biochem Biophys 395:137-145.

Hawkins CL, Rees MD, Davies MJ (2002). Superoxide radicals can act synergistically with hypochlorite to induce damage to proteins. FEBS Lett 510:41-44.

Hawkins CL, Pattison DI, Davies MJ (2003). Hypochlorite-induced oxidation of amino acids, peptides and proteins. Amino Acids 25:259-274.

Hidalgo E, Dominguez C (2000). Growth-altering effects of sodium hypochlorite in cultured human dermal fibroblasts. Life Sci 67:1331-1344.

Hidalgo E, Bartolome R, Dominguez C (2002). Cytotoxicity mechanisms of sodium hypochlorite in cultured human dermal fibroblasts and its bactericidal effectiveness. Chem Biol Interact 139:265-282

Hirshberg A, Amariglio N, Akrish S, Yahalom R, Rosenbaum H, Okon $\mathrm{E}$, et al. (2006). Traumatic ulcerative granuloma with stromal eosinophilia: a reactive lesion of the oral mucosa. Am J Clin Pathol 126:522-529.

Hoogendoorn H (1976). Microbial aspects of dental caries. The inhibitory action of the lactoperoxidase system on Streptococcus mutans and other microorganisms. Microb Aspects Dent Caries Proc Workshop 2:353-357.

Hunt SM, Hamilton MA, Stewart PS (2005). A 3D model of antimicrobial action on biofilms. Water Sci Technol 52:143-148.

Huque J, Kota K, Yamaga M, Iwaku M, Hoshino E (1998). Bacterial eradication from root dentine by ultrasonic irrigation with sodium hypochlorite. Int Endod J 31:242-250.

Hurst JK, Barrette WC Jr, Michel BR, Rosen H (1991). Hypochlorous acid and myeloperoxidase-catalyzed oxidation of iron-sulfur clusters in bacterial respiratory dehydrogenases. Eur J Biochem 202:1275-1282.

Ihalin R, Loimaranta V, Lenander-Lumikari M, Tenovuo J (2001). The sensitivity of Porphyromonas gingivalis and Fusobacterium nucleatum to different (pseudo)halide-peroxidase combinations compared with mutans streptococci. J Med Microbiol 50:42-48.

Ihalin R, Nuutila J, Loimaranta V, Lenander M, Tenovuo J, Lilius EM (2003). Susceptibility of Fusobacterium nucleatum to killing by peroxidase-iodide-hydrogen peroxide combination in buffer solution and in human whole saliva. Anaerobe 9:23-30.

Ihalin R, Loimaranta V, Tenovuo J (2006). Origin, structure, and biological activities of peroxidases in human saliva. Arch Biochem Biophys 445:261-268.

Jenkins GN (1999). Review of fluoride research since 1959. Arch Oral Biol 44:985-992.

Jones MN, Hill KJ, Kaszuba M, Creeth JE (1998). Antibacterial reactive liposomes encapsulating coupled enzyme systems. Int $J$ Pharm 162:107-117.

Kanofsky JR (1991). Peroxidase-catalyzed generation of singlet oxygen and of free radicals. In: Peroxidases in chemistry and biology. Everse J, Everse KG, Grisham MB, editors. Boston: CRC Publishers, pp. 219-231.

Kettle AJ, Winterbourn CC (2005). Do neutrophils produce ozone? An appraisal of current evidence. BioFactors 24:41-45.

Kettle AJ, Clark BM, Winterbourn CC (2004). Superoxide converts indigo carmine to isatin sulfonic acid: implications for the hypothesis that neutrophils produce ozone. $J$ Biol Chem 279:18521-18525

King DA, Hannum DM, Qi JS, Hurst JK (2004). Hocl-mediated cell death and metabolic dysfunction in the yeast Saccharomyces cerevisiae. Arch Biochem Biophys 423:170-181.

Kirstila V, Lenander-Lumikari M, Tenovuo J (1994). Effects of a lactoperoxidase-system-containing toothpaste on dental plaque and whole saliva in vivo. Acta Odontol Scand 52:346-353.

Klebanoff SJ (2005). Myeloperoxidase: friend and foe. J Leukoc Biol 77:598-625.

Klein I, Nagler RM, Toffler R, van der Vliet A, Reznick AZ (2003). Effect of cigarette smoke on oral peroxidase activity in human saliva: role of hydrogen cyanide. Free Radic Biol Med 35:14481452.

Korpela A, Yu X, Loimaranta V, Lenander-Lumikari M, VaccaSmith A, Wunder D, et al. (2002). Lactoperoxidase inhibits glucosyltransferases from Streptococcus mutans in vitro. Caries Res 36:116-121.

Kou F, Takahama U (1995). Hydrogen peroxide-induced luminescence and evolution of molecular oxygen in human saliva. Arch Oral Biol 40:15-21.

Kowolik MJ, Grant M (1983). Myeloperoxidase activity in human gingival crevicular neutrophils. Arch Oral Biol 28:293-295.

Lamberts BL, Pruitt KM, Pedersen ED, Golding MP (1984). Comparison of salivary peroxidase system components in cariesfree and caries-active naval recruits. Caries Res 18:488-494.

Lamster IB, Novak MJ (1992). Host mediators in gingival crevicular fluid-implications for the pathogenesis of periodontal disease. Crit Rev Oral Biol Med 3:31-60.

Lappert MF, Pyszora H (1966). Pseudohalides of group IIIb and IVb elements. In: Advances in inorganic chemistry and radiochemistry. Vol. 9. Sharpe AG, editor. USA: Academic Press, pp. 133-184.

Lemma K, Ashby MT (2008). Reactive sulfur species: kinetics and mechanism of the equilibrium between cysteine sulfenyl thiocyanate and cysteine thiosulfinate ester in acidic aqueous solution. J Org Chem 73:3017-3023.

Lenander-Lumikari M, Tenovuo J, Mikola H (1993). Effects of a lactoperoxidase system-containing toothpaste on levels of hypothiocyanite and bacteria in saliva. Caries Res 27:285-291.

Lenander-Lumikari M, Loimaranta V, Hannuksela S, Tenovuo J, Ekstrand J (1997). Combined inhibitory effect of fluoride and hypothiocyanite on the viability and glucose metabolism of Streptococcus mutans, serotype c. Oral Microbiol Immunol 12:231-235.

Leung-Toung R, Li W, Tam TF, Karimian K (2002). Thiol-dependent 
enzymes and their inhibitors: a review. Curr Med Chem 9:9791002 .

Li H, Thompson I, Carter P, Whiteley A, Bailey M, Leifert C, et al. (2007). Salivary nitrate - an ecological factor in reducing oral acidity. Oral Microbiol Immunol 22:67-71.

Lohinai ZM, Szabo C (1998). Role of nitric oxide in physiology and pathophysiology of periodontal tissues. Med Sci Monit 4:10891095.

Lohinai Z, Stachlewitz R, Virag L, Szekely AD, Hasko G, Szabo C (2001). Evidence for reactive nitrogen species formation in the gingivomucosal tissue. $J$ Dent Res 80:470-475.

Lopatin DE, LaBelle D, Lee SW (1991). Measurement of relative avidity of antibodies reactive with Porphyromonas (Bacteroides) gingivalis in the sera of subjects having adult periodontitis. $J$ Periodontal Res 26:167-175.

Lumikari M, Soukka T, Nurmio S, Tenovuo J (1991). Inhibition of the growth of Streptococcus mutans, Streptococcus sobrinus and Lactobacillus casei by oral peroxidase systems in human saliva. Arch Oral Biol 36:155-160.

Lundberg JO, Weitzberg E, Cole JA, Benjamin N (2004). Opinion: Nitrate, bacteria and human health. Nat Rev Microbiol 2:593-602.

Lundquist P, Rosling H, Sörbo B (1988). The origin of hydrogen cyanide in breath. Arch Toxicol 61:270-274.

Luppens SBI, Reij MW, van der Heijden RWL, Rombouts FM, Abee T (2002). Development of a standard test to assess the resistance of Staphylococcus aureus biofilm cells to disinfectants. Appl Environ Microbiol 68:4194-4200.

Mainnemare A, Megarbane B, Soueidan A, Daniel A, Chapple ILC (2004). Hypochlorous acid and taurine-N-monochloramine in periodontal diseases. $J$ Dent Res 83:823-831.

Marnett LJ (2002). Oxy radicals, lipid peroxidation and DNA damage. Toxicology 181-182:219-222.

Marquis RE (1995). Antimicrobial actions of fluoride for oral bacteria. Can J Microbiol 41:955-964.

Marquis RE, Clock SA, Mota-Meira M (2003). Fluoride and organic weak acids as modulators of microbial physiology. FEMS Microbiol Rev 26:493-510.

Marsh PD (2003). Are dental diseases examples of ecological catastrophes? Microbiology 149(Pt 2):279-294.

Marshall VME, Reiter B (1980). Comparison of the antibacterial activity of the hypothiocyanite anion towards Streptococcus lactis and Escherichia coli. J Gen Microbiol 120:513-516.

Martinez GR, Di Mascio P, Bonini MG, Augusto O, Briviba K, Sies H, et al. (2000). Peroxynitrite does not decompose to singlet oxygen $\left({ }^{1} \mathrm{O}_{2}\right)$ and nitroxyl $\left(\mathrm{NO}^{-}\right)$. Proc Natl Acad Sci USA 97:1030710312.

Mattana A, Juliano C, Bennardini F, Mignano M, Marceddu S, Picci V, et al. (1992). Hydrogen peroxide-induced cytotoxicity in cultured epithelial cells (WISH): a functional and morphological study. Toxicol in Vitro 6:533-541.

McKnight GM, Duncan CW, Leifert C, Golden MH (1999). Dietary nitrate in man: friend or foe? Br J Nutr 81:349-358.

Mealey BL, Oates TW (2006). Diabetes mellitus and periodontal diseases. J Periodontol 77:1289-1303.

Meister A (1988). Glutathione metabolism and its selective modification. J Biol Chem 263:17205-17208.

Mezei MM, Tron VA, Stewart WD, Rivers JK (1995). Eosinophilic ulcer of the oral mucosa. J Am Acad Dermatol 33:734-740.

Mikami M, Kato C, Saito K (2003). Characterization of the cell surface substances of Fusobacterium nucleatum that induce a chemiluminescence response by human neutrophils. Nippon Shishubyo Gakkai Kaishi [J Jpn Assoc Periodontol] 45:215-228 [article in Japanese].

Moller AJ, Fabricius L, Dahlén G, Sundqvist G, Happonen R-P (2004). Apical periodontitis development and bacterial response to endodontic treatment. Experimental root canal infections in monkeys with selected bacterial strains. Eur J Oral Sci 112:207215.

Mombelli A (2003). Periodontitis as an infectious disease: specific features and their implications. Oral Dis 9(Suppl 1):6-10.

Morabia A, Bernstein MS, Curtin F, Berode M (2001). Validation of self-reported smoking status by simultaneous measurement of carbon monoxide and salivary thiocyanate. Prev Med 32:82-88.

Morita M (1977). Inhibitory effects of some constituents of cigarette smoke on the lactate production of salivary microorganisms and Streptococcus mutans. Shika Kiso Igakkai Zasshi 19:349-365 [article in Japanese].

Nagayoshi M, Kitamura C, Fukuizumi T, Nishihara T, Terashita M (2004). Antimicrobial effect of ozonated water on bacteria invading dentinal tubules. $J$ Endod 30:778-781.

Nagy P, Ashby MT (2007). Reactive sulfur species: kinetics and mechanisms of the oxidation of cysteine by hypohalous acid to give cysteine sulfenic acid. J Am Chem Soc 129:14082-14091.

Nagy P, Alguindigue SS, Ashby MT (2006a). Lactoperoxidasecatalyzed oxidation of thiocyanate by hydrogen peroxide: a reinvestigation of hypothiocyanite by nuclear magnetic resonance and optical spectroscopy. Biochemistry 45:12610-12616.

Nagy P, Beal JL, Ashby MT (2006b). Thiocyanate is an efficient endogenous scavenger of the phagocytic killing agent hypobromous acid. Chem Res Toxicol 19:587-593.

Nagy P, Lemma K, Ashby MT (2007a). Kinetics and mechanism of the comproportionation of hypothiocyanous acid and thiocyanate to give thiocyanogen in acidic aqueous solution. Inorg Chem 46:285-292.

Nagy P, Lemma K, Ashby MT (2007b). Reactive sulfur species: kinetics and mechanisms of the reaction of cysteine thiosulfinate ester with cysteine to give cysteine sulfenic acid. J Org Chem 72:8838-8846.

Nagy P, Wang X, Lemma K, Ashby MT (2007c). Reactive sulfur species: hydrolysis of hypothiocyanite to give thiocarbamate-Soxide. J Am Chem Soc 129:15756-15757.

Nimmo SLA, Lemma K, Ashby MT (2007). Reactions of cysteine sulfenyl thiocyanate with thiols to give unsymmetrical disulfides. Heteroatom Chemistry 18:467-471.

Oliveby A, Lagerlöf F, Ekstrand J, Dawes C (1989). Studies on fluoride excretion in human whole saliva and its relation to flow rate and plasma fluoride levels. Caries Res 23:243-246.

Oram JD, Reiter B (1966). The inhibition of streptococci by lactoperoxidase, thiocyanate and hydrogen peroxide. The oxidation of thiocyanate and the nature of the inhibitory compound. Biochem $J$ 100:382-388

Ozok AR, Wu MK, Luppens SBI, Wesselink PR (2007). Comparison of growth and susceptibility to sodium hypochlorite of monoand dual-species biofilms of Fusobacterium nucleatum and Peptostreptococcus (Micromonas) micros. J Endod 33:819-822.

Packer L (2002). Superoxide dismutase. In: Methods in enzymology. Vol. 349. San Diego, CA: Academic press, 400 pp.

Palazzolo AM, Suquet C, Konkel ME, Hurst JK (2005). Green fluorescent protein-expressing Escherichia coli as a selective probe for $\mathrm{HOCl}$ generation within neutrophils. Biochemistry 44:6910-6919.

Pannala AS, Mani AR, Spencer JPE, Skinner V, Bruckdorfer KR, Moore KP, et al. (2003). The effect of dietary nitrate on salivary, plasma, and urinary nitrate metabolism in humans. Free Radic Biol Med 34:576-584.

Pattison DI, Davies MJ (2001). Absolute rate constants for the reaction of hypochlorous acid with protein side chains and peptide bonds. Chem Res Toxicol 14:1453-1464.

Pattison DI, Davies MJ (2004). Kinetic analysis of the reactions of hypobromous acid with protein components: implications for cellular damage and use of 3-bromotyrosine as a marker of oxidative stress. Biochemistry 43:4799-4809. 
Peskin AV, Winterbourn CC (2006). Taurine chloramine is more selective than hypochlorous acid at targeting critical cysteines and inactivating creatine kinase and glyceraldehyde-3-phosphate dehydrogenase. Free Radic Biol Med 40:45-53.

Phan TN, Kirsch AM, Marquis RE (2001). Selective sensitization of bacteria to peroxide damage associated with fluoride inhibition of catalase and pseudocatalase. Oral Microbiol Immunol 16:28-33.

Prousek J (2007). Fenton chemistry in biology and medicine. Pure Appl Chem 79:2325-2338.

Pruitt KM, Adamson M, Arnold R (1979). Lactoperoxidase binding to streptococci. Infect Immun 25:304-309.

Pruitt KM, Mansson-Rahemtulla B, Baldone DC, Rahemtulla F (1988). Steady-state kinetics of thiocyanate oxidation catalyzed by human salivary peroxidase. Biochemistry 27:240-245.

Pullar JM, Vissers MCM, Winterbourn CC (2000). Living with a killer: the effects of hypochlorous acid on mammalian cells. IUBMB Life 50:259-266.

Qian M, Eaton JW, Wolff SP (1997). Cyanate-mediated inhibition of neutrophil myeloperoxidase activity. Biochem $J$ 326(Pt 1):159166.

Quinn MT (2005). The neutrophil respiratory burst oxidase. In: Neutrophils. 2nd ed. Gabrilovich DI. editor. London: Imperial College Press, pp. 35-84.

Radcliffe CE, Potouridou L, Qureshi R, Habahbeh N, Qualtrough A, Worthington $\mathrm{H}$, et al. (2004). Antimicrobial activity of varying concentrations of sodium hypochlorite on the endodontic microorganisms Actinomyces israelii, A. naeslundii, Candida albicans and Enterococcus faecalis. Int Endod J 37:438-446.

Reszka KJ, Matuszak Z, Chignell CF (1997). Lactoperoxidasecatalyzed oxidation of the anticancer agent mitoxantrone by nitrogen dioxide $\left(\mathrm{NO}_{2}{ }^{-}\right)$radicals. Chem Res Toxicol 10:1325-1330.

Reszka KJ, Matuszak Z, Chignell CF (1998). Lactoperoxidasecatalyzed oxidation of melanin by reactive nitrogen species derived from nitrite $\left(\mathrm{NO}_{2}^{-}\right)$: an EPR study. Free Radic Biol Med 25:208-216.

Reszka KJ, Matuszak Z, Chignell CF, Dillon J (1999). Oxidation of biological electron donors and antioxidants by a reactive lactoperoxidase metabolite from nitrite $\left(\mathrm{NO}_{2}^{-}\right)$: an EPR and spin trapping study. Free Radic Biol Med 26:669-678.

Ris-Stalpers C (2006). Physiology and pathophysiology of the duoxes. Antioxid Redox Signal 8:1563-1572.

Riva A, Puxeddu P, Del Fiacco M, Testa-Riva F (1978). Ultrastructural localization of endogenous peroxidase in human parotid and submandibular glands. J Anat 127(Pt 1):181-191.

Rivera-Hidalgo F (2003). Smoking and periodontal disease. Periodontol 2000 32:50-58.

Ryan CS, Kleinberg I (1995). Bacteria in human mouths involved in the production and utilization of hydrogen peroxide. Arch Oral Biol 40:753-763.

Sassone LM, Fidel R, Fidel S, Vieira M, Hirata R Jr (2003a). The influence of organic load on the antimicrobial activity of different concentrations of $\mathrm{NaOCl}$ and chlorhexidine in vitro. Int Endod $J$ 36:848-852.

Sassone LM, Fidel RA, Fidel SR, Dias M, Hirata RJ (2003b). Antimicrobial activity of different concentrations of $\mathrm{NaOCl}$ and chlorhexidine using a contact test. Braz Dent J 14:99-102.

Sato EF, Choudhury T, Nishikawa T, Inoue M (2008). Dynamic aspect of reactive oxygen and nitric oxide in oral cavity. $J$ Clin Biochem Nutr 42:8-13.

Schraufstatter IU, Browne K, Harris A, Hyslop PA, Jackson JH, Quehenberger O, et al. (1990). Mechanisms of hypochlorite injury of target cells. J Clin Invest 85:554-562.

Segal R, Dunford HB, Morrison M (1968). Kinetics of fluoride binding by lactoperoxidase. Can J Biochem 46:1471-1474.

Sena NT, Gomes B, Vianna ME, Berber VB, Zaia AA, Ferraz CCR, et al. (2006). In vitro antimicrobial activity of sodium hypochlorite and chlorhexidine against selected single-species biofilms. Int Endod J 39:878-885.

Shapira L, Wilensky A, Kinane DF (2005). Effect of genetic variability on the inflammatory response to periodontal infection. $J$ Clin Periodontol 32(Suppl 6):72-86.

Shenkin JD, Broffitt B, Levy SM, Warren JJ (2004). The association between environmental tobacco smoke and primary tooth caries. $J$ Public Health Dent 64:184-186.

Shin K, Tomita M, Lonnerdal B (2000). Identification of lactoperoxidase in mature human milk. J Nutr Biochem 11:94-102.

Silva Mendez LS, Allaker RP, Hardie JM, Benjamin N (1999). Antimicrobial effect of acidified nitrite on cariogenic bacteria. Oral Microbiol Immunol 14:391-392.

Singer DL, Chatterjee R, Denepitiya L, Kleinberg I (1983). A comparison of the acid-base metabolisms of pooled human dental plaque and salivary sediment. Arch Oral Biol 28:29-35.

Sitte N, Von Zglinicki T (2003). Free radical production and antioxidant defense: a primer. In: Aging at the molecular level (biology of aging and Its modulation). Von Zglinicki T, editor. Dordrecht, the Netherlands: Kluwer Academic Publishers, pp. 1-10.

Smalley JW (1994). Pathogenic mechanisms in periodontal disease. Adv Dent Res 8:320-328.

Smirnova GV, Oktyabrsky ON (2005). Glutathione in bacteria. Biochemistry (Moscow) 70:1199-1211.

Smith AJ, Benjamin N, Weetman DA, Mackenzie D, MacFarlane TW (1999). The microbial generation of nitric oxide in the human oral cavity. Microb Ecol Health Dis 11:23-27.

Smith LL (2004). Oxygen, oxysterols, ouabain, and ozone: a cautionary tale. Free Radic Biol Med 37:318-324.

Soszynski M, Zavodnik IB, Zavodnik LB, Zylinska L, Bartosz G, Bryszewska M (2002). Hypochlorous acid inhibits glutathione S-conjugate export from human erythrocytes. Biochim Biophys Acta $1564: 479-486$.

Spahn JD (2007). Asthma biomarkers in sputum. Immunol Allergy Clin North Am 27:607-622.

Spratt DA, Pratten J, Wilson M, Gulabivala K (2001). An in vitro evaluation of the antimicrobial efficacy of irrigants on biofilms of root canal isolates. Int Endod J 34:300-307.

Stewart PS (1994). Biofilm accumulation model that predicts antibiotic resistance of Pseudomonas aeruginosa biofilms. Antimicrob Agents Chemother 38:1052-1058.

Stewart PS, Raquepas JB (1995). Implications of reaction-diffusion theory for the disinfection of microbial biofilms by reactive antimicrobial agents. Chem Eng Sci 50:3099-3104.

Stewart PS, Rayner J, Roe F, Rees WM (2001). Biofilm penetration and disinfection efficacy of alkaline hypochlorite and chlorosulfamates. J Appli Microbiol 91:525-532.

Stewart PS, Mukherjee PK, Ghannoum MA (2004). Biofilm antimicrobial resistance. In: Microbial biofilms. Ghannoum M, O'Toole G, editors. Washington, DC; ASM Press, pp. 250-268.

Sun S, Li X, Zhang G, Ma H, Zhang D, Bao Z (2006). Determination of $\mathrm{H}_{2} \mathrm{O}_{2}$-dependent generation of singlet oxygen from human saliva with a novel chemiluminescence probe. Biochim Biophys Acta 1760:440-444.

Suzuki T, Ohshima H (2003). Modification by fluoride, bromide, iodide, thiocyanate and nitrite anions of reaction of a myeloperoxidase- $\mathrm{H}_{2} \mathrm{O}_{2}-\mathrm{Cl}$ system with nucleosides. Chem Pharm Bull 51:301-304.

Tahboub YR, Galijasevic S, Diamond MP, Abu-Soud HM (2005). Thiocyanate modulates the catalytic activity of mammalian peroxidases. J Biol Chem 280:26129-26136.

Takahama U (1993). Hydrogen peroxide-dependent generation of singlet molecular oxygen by human saliva: its detection by chemiluminescence from a cypridina luciferin analog. Photochem Photobiol 57:376-379. 
Tenovuo J (1976). The variation of salivary peroxidase activities in persons of different oral health. Acta Odontol Scand 34:163-168.

Tenovuo J (1979). Formation of the bacterial inhibitor, hypothiocyanite ion, by cell-bound lactoperoxidase. Caries Res 13:137-143.

Tenovuo J, Larjava H (1984). The protective effect of peroxidase and thiocyanate against hydrogen peroxide toxicity assessed by the uptake of $[3 \mathrm{H}]$-thymidine by human gingival fibroblasts cultured in vitro. Arch Oral Biol 29:445-451.

Tenovuo J, Makinen KK (1976). Concentration of thiocyanate and ionizable iodine in saliva of smokers and nonsmokers. $J$ Dent Res 55:661-663.

Tenovuo J, Söderling E, Sievers G (1985). The peroxidase system in human tears. In: Protides of the biological fluids. Vol. 32. Peters H, editor. Oxford, UK: Pergamon Press, pp. 107-110.

Thibodeau EA, Bowen WH, Marquis RE (1985). pH-dependent fluoride inhibition of peroxidase activity. $J$ Dent Res 64:12111213.

Thomas EL, Bates KP, Jefferson MM (1980). Hypothiocyanite ion: detection of the antimicrobial agent in human saliva. $J$ Dent Res 59:1466-1472

Thomas EL, Pera KA, Smith KW, Chwang AK (1983). Inhibition of Streptococcus mutans by the lactoperoxidase antimicrobial system. Infect Immun 39:767-778.

Thomas EL, Jefferson MM, Joyner RE, Cook GS, King CC (1994a). Leukocyte myeloperoxidase and salivary lactoperoxidase: identification and quantitation in human mixed saliva. $J$ Dent Res 73:544-555.

Thomas EL, Milligan TW, Joyner RE, Jefferson MM (1994b). Antibacterial activity of hydrogen peroxide and the lactoperoxidase-hydrogen peroxide-thiocyanate system against oral streptococci. Infect Immun 62:529-535.

Thomas EL, Bozeman PM, Jefferson MM, King CC (1995). Oxidation of bromide by the human leukocyte enzymes myeloperoxidase and eosinophil peroxidase. Formation of bromamines. $J$ Biol Chem 270:2906-2913.

Thongboonkerd V, Luengpailin J, Cao J, Pierce WM, Cai J, Klein JB, et al. (2002). Fluoride exposure attenuates expression of Streptococcus pyogenes virulence factors. J Biol Chem 277:1659916605; erratum in J Biol Chem 277:42417, 2002.

Tipton DA, Braxton SD, Dabbous MK (1995a). Effects of a bleaching agent on human gingival fibroblasts. $J$ Periodontol 66:7-13.

Tipton DA, Braxton SD, Dabbous MK (1995b). Role of saliva and salivary components as modulators of bleaching agent toxicity to human gingival fibroblasts in vitro. J Periodontol 66:766-774.

Tsuchiya M, Asada A, Kasahara E, Sato EF, Shindo M, Inoue M (2002). Smoking a single cigarette rapidly reduces combined concentrations of nitrate and nitrite and concentrations of antioxidants in plasma. Circulation 105:1155-1157.

Tsuge K, Kataoka M, Seto Y (2000). Cyanide and thiocyanate levels in blood and saliva of healthy adult volunteers. J Health Sci 46:343350 .

Ueda T, Sakamaki K, Kuroki T, Yano I, Nagata S (1997). Molecular cloning and characterization of the chromosomal gene for human lactoperoxidase. Eur J Biochem 243:32-41.

Uehara Y, Agematsu K, Kikuchi K, Matsuzaki S, Imai S, Takamoto M, et al. (2006). Secretory IgA, salivary peroxidase, and catalasemediated microbicidal activity during hydrogen peroxide catabolism in viridans streptococci: pathogen coaggregation. $J$ Infect Dis 194:98-107.

van Dalen CJ, Whitehouse MW, Winterbourn CC, Kettle AJ (1997). Thiocyanate and chloride as competing substrates for myeloperoxidase. Biochem J 327(Pt 2):487-492.

van den Abbeele A, Pourtois M, Courtois P (1992). Fluoride inhibition of scn- and cl-peroxidase activities in whole saliva and of recombinant myeloperoxidase. Influence of $\mathrm{pH}$ and hydrogen peroxide concentration. J Biol Buccale 20:219-224. van den Abbeele A, Courtois P, Pourtois M (1995). The influence of different fluoride salts on fluoride-mediated inhibition of peroxidase activity in human saliva. Arch Oral Biol 40:695-698.

van der Hoeven JS, Camp PJ (1993). Mixed continuous cultures of Streptococcus mutans with Streptococcus sanguis or with Streptococcus oralis as a model to study the ecological effects of the lactoperoxidase system. Caries Res 27:26-30.

van der Vliet A, Eiserich JP, Halliwell B, Cross CE (1997). Formation of reactive nitrogen species during peroxidase-catalyzed oxidation of nitrite. A potential additional mechanism of nitric oxidedependent toxicity. J Biol Chem 272:7617-7625.

Van Dyke TE (2007). Control of inflammation and periodontitis. Periodontol 2000 45:158-166.

Van Haeringen NJ, Ensink FTE, Glasius E (1979). The peroxidasethiocyanate-hydrogenperoxide system in tear fluid and saliva of different species. Exp Eye Res 28:343-347.

Van Loveren C (1990). The antimicrobial action of fluoride and its role in caries inhibition. $J$ Dent Res 69(Spec Iss):676-681.

Vannini L, Lanciotti R, Baldi D, Guerzoni ME (2004). Interactions between high pressure homogenization and antimicrobial activity of lysozyme and lactoperoxidase. Int J Food Microbiol 94:123135.

Vianna ME, Gomes B, Berber VB, Zaia AA, Ferraz CCR, de SouzaFilho FJ (2004). In vitro evaluation of the antimicrobial activity of chlorhexidine and sodium hypochlorite. Oral Surg Oral Med Oral Pathol Oral Radiol Endod 97:79-84.

Vile GF, Rothwell LA, Kettle AJ (2000). Initiation of rapid, p53dependent growth arrest in cultured human skin fibroblasts by reactive chlorine species. Arch Biochem Biophys 377:122-128.

Vissers MCM, Pullar JM, Hampton MB (1999). Hypochlorous acid causes caspase activation and apoptosis or growth arrest in human endothelial cells. Biochem J 344(Pt 2):443-449.

Waddington RJ, Moseley R, Embery G (2000). Reactive oxygen species: a potential role in the pathogenesis of periodontal diseases. Oral Dis 6:138-151.

Wang Y (2008). Bulky DNA lesions induced by reactive oxygen species. Chem Res Toxicol 21:276-281.

Wang Z, Nicholls SJ, Rodriguez ER, Kummu O, Hoerkkoe S, Barnard $\mathrm{J}$, et al. (2007). Protein carbamylation links inflammation, smoking, uremia and atherogenesis. Nat Med 13:1176-1184.

Ward PA (1991). Mechanisms of endothelial cell killing by hydrogen peroxide or products of activated neutrophils. Am J Med 91(3C):89-94.

Webb BC, Willcox MDP, Thomas CJ, Harty DWS, Knox KW (1995). The effect of sodium-hypochlorite on potential pathogenic traits of Candida albicans and other Candida species. Oral Microbiol Immunol 10:334-341.

Wentworth AD, Jones LH, Wentworth P Jr, Janda KD, Lerner RA (2000). Antibodies have the intrinsic capacity to destroy antigens. Proc Natl Acad Sci USA 97:10930-10935.

Wentworth P Jr, McDunn JE, Wentworth AD, Takeuchi C, Nieva J, Jones T, et al. (2002). Evidence for antibody-catalyzed ozone formation in bacterial killing and inflammation. Science 298:21952199.

Weuffen W, Franzke C, Thürkow B (1984). Alimentary ingestion, analysis and biological significance of thiocyanate. Nährung 28:341-355.

Wever R, Bakkenist ARJ (1980). The interaction of myeloperoxidase with ligands as studied by EPR. Biochim Biophys Acta 612:178184.

White JW Jr (1975). Relative significance of dietary sources of nitrate and nitrite. J Agric Food Chem 23:886-891.

White WE Jr, Pruitt KM, Mansson-Rahemtulla B (1983). Peroxidasethiocyanate-peroxide antibacterial system does not damage DNA. Antimicrob Agents Chemother 23:267-272.

Winniczuk PP, Parish ME (1997). Minimum inhibitory concentrations 
of antimicrobials against micro-organisms related to citrus juice. Food Microbiol 14:373-381.

Winterbourn CC (1995). Toxicity of iron and hydrogen peroxide: the Fenton reaction. Toxicol Lett 82/83:969-974.

Winterbourn CC, Kettle AJ (2000). Biomarkers of myeloperoxidasederived hypochlorous acid. Free Radic Biol Med 29:403-409.

Woldring MG (1955). Free amino acids of human saliva: a chromatographic investigation. J Dent Res 34:248-256.

Wong-Chong GM, Ghosh RS, Bushey JT, Ebbs SD, Neuhauser EF (2006). Natural sources of cyanide. In: Cyanide in water and soil. Chemistry, risk \& management. Dzombak DA, Ghosh RS, WongChong GM, editors. Boca Raton, FL: CRC Press, pp. 25-40.

Wood JL (1975). Biochemistry of thiocyanates. In: Chemistry and biochemistry of thiocyanic acid \& its derivatives. New York: Academic Press Inc., pp. 156-221.

Wunder D, Bowen WH (1999). Action of agents on glucosyl- transferases from Streptococcus mutans in solution and adsorbed to experimental pellicle. Arch Oral Biol 44:203-214.

Yesilsoy C, Whitaker E, Cleveland D, Phillips E, Trope M (1995). Antimicrobial and toxic effects of established and potential rootcanal irrigants. $J$ Endod 21:513-515.

Yu X, Loimaranta V, Lenander-Lumikari M, Wunder D, Bowen WH, Tenuvuo J (2000). Effect of lactoperoxidase system on glucosyltransferase D of Streptococcus mutans. Chin J Dent Res 3:61-64.

Zgliczynski JM, Stelmaszynska T, Olszowska E, Krawczyk A, Kwasnowska E, Wrobel JT (1983). Peroxidative oxidation of halides catalyzed by myeloperoxidase. Effect of fluoride on halide oxidation. Acta Biochim Pol 30:213-222.

Zhu PC (2007). New biocides development. The combined approach of chemistry and microbiology (ACS Symposium Series). New York: Oxford University Press, p. 967. 